\title{
Diversity and distribution of adeonid bryozoans (Cheilostomata: Adeonidae) in Japanese waters
}

\author{
Masato HIROSE \\ Atmosphere and Ocean Research Institute, The University of Tokyo, \\ Kashiwanoha 5-1-5, Kashiwa, Chiba 277-8564, Japan. \\ Email: mhirose64@gmail.com \\ urn:Isid:zoobank.org:author:C6C49C49-B4DF-46B9-97D7-79DE2C942214
}

\begin{abstract}
Adeonid bryozoans construct antler-like erect colonies and are common in bryozoan assemblages along the Japanese Pacific coast. The taxonomy of Japanese adeonid species, however, has not been studied since their original descriptions more than 100 years ago. In the present study, adeonid specimens from historical collections and material recently collected along the Japanese coast are examined. Eight adeonid species in two genera were detected, of which Adeonella jahanai sp. nov., Adeonellopsis parvirostrum sp. nov., and Adeonellopsis toyoshioae sp. nov. are described as new species based on the branch width, size and morphology of frontal or suboral avicularia, shape and size of areolar pores, and size of the spiramen. Adeonellopsis arculifera (Canu \& Bassler, 1929) is a new record for Japan. Lectotypes for Adeonellopsis japonica (Ortmann, 1890) and Adeonella sparassis (Ortmann, 1890) were selected among Ortmann's syntypes. Most species of Adeonellopsis around Japan have a southern distribution from Sagami Bay to Okinawa, while $A$.japonica shows a more northern distribution from Kouchi to Otsuchi. In contrast, Adeonellopsis arculifera was collected only from southwestern Japan. A key to Japanese adeonid species is provided.
\end{abstract}

Keywords. Adeonella, Adeonellopsis, diversity, distribution, Japan.

Hirose M. 2016. Diversity and distribution of adeonid bryozoans (Cheilostomata: Adeonidae) in Japanese waters. European Journal of Taxonomy 203: 1-41. http://dx.doi.org/10.5852/ejt.2016.203

\section{Introduction}

Order Cheilostomata in Class Gymnolaemata is the most speciose group of bryozoans in modern marine environments (Bock \& Gordon 2013). While most cheilostome colonies are encrusting, forming an essentially 2-dimensional layer on the substrate, there are also many types of erect morphology in which the colony rises above the substrate in 3-dimensional space. Large, erect bryozoan colonies have contributed to the formation of bryozoan reefs or thickets from the Paleozoic to the present (Cuffey 1974, 1977; Lombardi et al. 2014; McKinney \& Jackson 1989; Scholz et al. 2005; Probert \& Batham 1979; Carter et al. 1985; Batson \& Probert 2000; Taylor \& James 2013; Wood \& Probert 2013). Adeonid bryozoans (e.g., Adeonella Busk, 1884, Adeona Lamouroux, 1812, Adeonellopsis MacGillivray, 1886) form large, erect colonies with many flat, narrow, dichotomous branches, or are cribrate in form, which can be viewed as derived from dichotomously branched colonies, and contribute to assemblages of erect bryozoans in Japan (Hirose et al. 2012). 
The family Adeonidae consists of approximately 10 genera and 106 species (Bock \& Gordon 2013). One of the largest genera in the family, Adeonellopsis, comprises about 50 species that are almost globally distributed but are absent from higher latitudes (or alternatively: boreal and arctic waters). Another large genus, Adeonella, also comprises about 50 species, distributed in the Indo-West Pacific, Mediterranean, and Atlantic. Adeonellopsis has been reported from Eocene deposits and is common throughout the later Cenozoic to Recent. Adeonella has also been reported from Eocene deposits in Europe, but is more common in the present-day fauna. Hayward \& Cook $(1979,1983)$ and Hayward $(1981,1988)$ described 27 new species of Adeonella from South Africa, where its diversity is remarkably high on the east coast (Hayward 1983, 1988). Compared to Adeonella, Adeonellopsis is more common and diverse in Australia and throughout the Indo-West Pacific. The Adeonidae have received a relatively great amount of attention over the past decades, a number of new species were introduced, and several known species revised (e.g., Cook 1982; Arístegui 1985; Hayward 1988; Amui 2005; Rosso \& Novosel 2010; Almeida et al.2015). Moreover, owing to their complexity at zooidal and zoarial level, the ontogeny and astogeny of the Adeonidae is fairly well known (e.g., Cook 1973; Cheetham \& Hayek 1983; Wass 1991; Lidgard \& Buckley 1994; Lidgard 1996; Bock \& Cook 2000, 2004; Smith et al. 2001).

Busk (1884) first described Adeonella as a genus in the family Adeonidae. Gregory (1893) later established the family Adeonellidae for Adeonella and related genera. Some researchers followed Busk's original classification (Canu \& Bassler 1920, 1923, 1929; Harmer 1957), and Cook (1973) reported significant differences in frontal shield structure and development between Adeonella and the other genera in Adeonidae, and regarded Adeonella as clearly belonging in Adeonellidae. Recently, however, Adeonellidae has been considered as a junior synonym of Adeonidae (Bock \& Gordon 2013).

There are some previous records of adeonid bryozoans in Japan. Ortmann (1890) reported three species from Sagami Bay (Adeonella tuberculata Busk, 1884, and two new species, Adeonella japonica Ortmann, 1890 and Adeonella sparassis Ortmann, 1890). Ortmann's type material, however, has not been restudied in detail. Okada (1920) redescribed A. japonica from Sagami Bay and described a new species, Adeonella hexangularis Okada, 1920, from the vicinity of the Miura Peninsula adjoining Sagami Bay. Subsequently, Okada \& Mawatari (1938) reported A. japonica from Wakayama Prefecture. Mawatari (1952) also reported A. japonica and A. hexangularis from Wakayama Prefecture, without any descriptions. The taxonomy of the Japanese adeonid bryozoans has previously not been reviewed and is still largely dependent on the limited descriptions in Ortmann (1890), and their diversity and distribution around Japan remains poorly known.

For this study, I re-examined Ortmann's (1890) type specimens and examined other material collected in Japan over the past 130 years, as well as new material I collected personally. Here I review and describe or redescribe eight adeonid species in two genera from Japan, of which Adeonella jahanai sp. nov., Adeonellopsis parvirostrum sp. nov., and Adeonellopsis toyoshioae sp. nov. are described as new species, and summarize the distributions of all eight species around Japan.

\section{Material and methods}

\section{Material examined}

I examined specimens from Sagami Bay and surrounding areas (Appendix 1; Fig. 1A-B) collected by Ludwig Döderlein (1880-1881), Emperor Showa (1918-1971), and the National Museum of Nature and Science Tokyo (2001-2005; 2006-2010); see National Museum of Nature and Science (2007), Hirose (2010), and Spencer Jones et al. (2011) for historical overviews. The material is housed at the Musée Zoologique Strasbourg (MZS) and the National Museum of Nature and Science Tokyo (NSMT), which is now located in Tsukuba (Appendix 1). At the Seto Marine Biological Laboratory (SMBL) of Kyoto University, I examined a specimen of Adeonella japonica collected from the vicinity of the Kii 
Peninsula and reported by Okada \& Mawatari (1938). I also examined adeonid specimens collected by the R/V Albatross from Japan and Hawaii and now housed in the National Museum of Natural History (USNM), Washington, D.C.

I collected additional specimens by dredge, grab, and beam trawl from several localities in Japan (Fig. 1A, C; Appendix 2), including Otsuchi (Iwate Prefecture), Maizuru (Kyoto Prefecture), the Sagami Sea, north of Hachijo-jima (south of the Sagami Sea), southwest of Kochi (Kochi Prefecture), the Ariake Sea, Koshiki Strait (west of Kyushu), and the Nansei Islands from Tanegashima to Okinawa. All of this material has been deposited in the NSMT in Tsukuba.

\section{Preparation and observation of specimens}

Specimens were observed by light microscope and scanning electron microscope (SEM) at Hokkaido University and at the Atmosphere and Ocean Research Institute of the University of Tokyo (AORI). For SEM observation, part of each specimen was soaked in a sodium hypochlorite solution to remove the soft tissue, rinsed in water, air dried, and mounted with double-sided adhesive tape or silver paste on an aluminum SEM stub. At Hokkaido University, mounted specimens were coated with Au in a Hitachi E-1030 sputter-coater and observed at $15 \mathrm{kV}$ accelerating voltage with a Hitachi S-3000N SEM; at AORI, specimens were observed with a Hitachi Miniscope TM-1000 at $15 \mathrm{kV}$ accelerating voltage without sputter-coating. All fragments removed from specimens in the various collections for SEM observation were subsequently deposited in NMST.

Measurements were taken from SEM images with ImageJ v. 1.37 software (Image Processing and Analysis in Java, Wayne Rasband, National Institutes of Health, USA; http://rsb.info.nih.gov/ij/). Measurements in the text are presented in micrometers, with the range followed by the mean and standard deviation (in

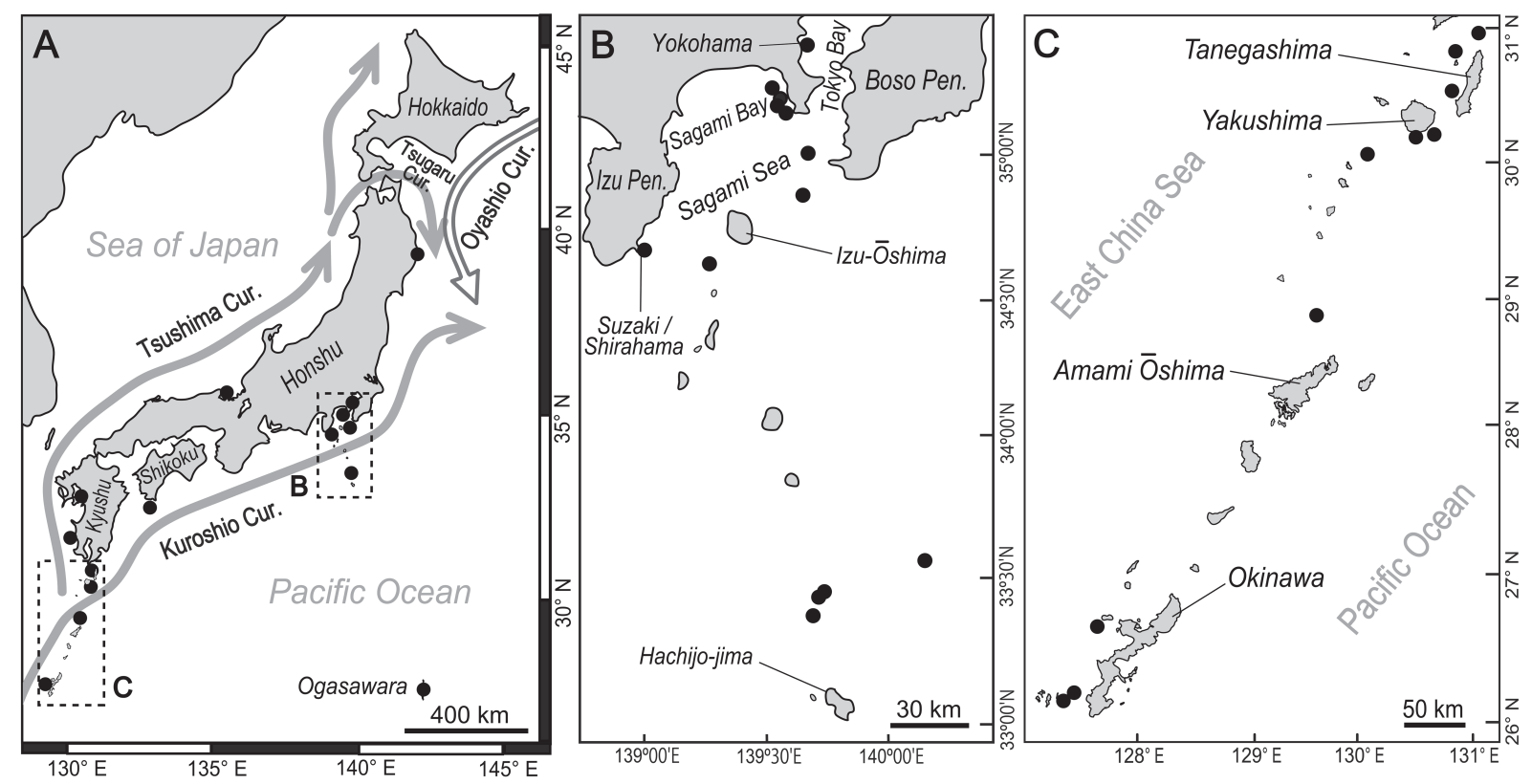

Fig. 1. Maps showing the localities where adeonid bryozoans were collected. A. Collecting localities around Japan. Gray arrows indicate warm currents, the unfilled arrow indicates the cold current. B. Enlargement from previous, showing the localities around Sagami Bay, Sagami Sea, and Hachijo-jima Island. C. Enlargement from map A, showing the localities along the Nansei Islands, from Tanegashima to Okinawa. 
parentheses). Sample sizes for measurements were $\mathrm{n}=2-115$, and measurements were generally taken from more than one colony. Abbreviations used for characters measured are as follows:

FAvL, FAvW = frontal avicularium length and width

SAvL, SAvW = suboral avicularium length and width

SOrL, SOrW = secondary orifice length and width

$\mathrm{SpL}, \mathrm{SpW} \quad=$ spiramen length and width

$\mathrm{ZL}, \mathrm{ZW} \quad=$ zooid length and width

\section{Results}

\section{Taxonomic descriptions}

Order Cheilostomata Busk, 1852

Suborder Neocheilostomina d'Hondt, 1985

Infraorder Ascophorina Levinsen, 1909

Superfamily Adeonoidea Vigneaux, 1949

Family Adeonidae Busk, 1884

\section{Remarks}

This family consists of approximately 10 genera and 106 species (Bock \& Gordon 2013). Most genera form erect colonies with flat, dichotomous branches (e.g., Adeonella and Adeonellopsis) or are cribrate in form (e.g., Adeona), although some genera form encrusting colonies (e.g., Reptadeonella Busk, 1884). Adeonella and Adeonellopsis differ in the type of frontal shield: Adeonella has a lepralioid shield in which a spiramen leads into the space above the sinus, and a distinct primary orifice, while Adeonellopsis is thought to have an umbonuloid frontal shield and the spiramen leads into the space above the frontal membrane (Cook 1973; Lidgard 1996; Berning et al. 2014). Adeonella and Adeonellopsis are also different in the arrangement of the spiramen and frontal/suboral avicularia; Adeonella generally has a monoporous spiramen and frontal avicularia in various positions, whereas Adeonellopsis has a monoporous or multiporous spiramen, with a suboral avicularium situated distal to the spiramen, directed distally or distolaterally.

Genus Adeonella Busk, 1884

Adeonella cf. lichenoides (Lamarck, 1816)

Figs 2-3

cf. Eschara lichenoides Lamarck, 1816: 176.

cf. Eschara platalea Busk, 1854: 90, pl. 105, figs 1-3, pl. 108, fig. 4.

cf. Adeonella lichenoides - Harmer 1957: 799. — Busk 1854: 90, pl. 106, figs 1-3. — Hayward 1988: 126, figs $1 \mathrm{C}, 2-3$.

cf. Adeonella platalea - Busk 1884: pl. 184, pl. 21, figs 4, 4a. - Harmer 1957: 809, pl. LIII, figs 2, 4-12. - Hayward 1983: 582, fig. 1A, C-D.

Adeona japonica - Mawatari 1952: pl. 12, fig. 1 [figured specimen].

\section{Material examined}

JAPAN: Izu, Sagami Sea, Emperor Showa collection (NSMT-BryR292, BryR297, BryR299, BryR303, BryR304, BryR315, BryR317, BryR324 (SEM specimen only), BryR357 (SEM specimen only), BryR358, BryR359, BryR360 (SEM specimen only), BryR365, BryR367, BryR377); Seto, Kii Peninsula (SMBL-Brz.17, some fragments NSMT-Te1049), Aug. 1936, probably specimen studied in Okada \& 
Mawatari (1938); Sagami Bay and Sagami Sea, collected by NSMT (NSMT-TeS13, TeS14, TeS30 (SEM specimen only)); off Shimoda, Izu Peninsula (NSMT-Te891); Koshiki Strait (NSMT-Te752); Ogasawara (NSMT-Te753, Te754, Te755, Te756).

\section{Measurements}

Autozooids. ZL: 298-526 (411 \pm 44$)$; ZW: 203-317 (239 \pm 21$)$; $\mathrm{n}=39$. SOrL: 44-92 (68 \pm 12$)$; SOrW:


$22-37(28 \pm 6) ; \mathrm{n}=18$.

Gonozooids. ZL: 456-521 (488 \pm 32$)$; ZW: 290-334(318 \pm 24$)$; n=3. SOrL: $75-77(76 \pm 1)$; SOrW: 93-122 $(111 \pm 16) ; \mathrm{n}=3$. FAvL: 61-67 (63 \pm 3$)$; FAvW: 25-36 (29 \pm 5$)$; $\mathrm{n}=4$. SpL: 34-38 (36 \pm 2$)$; SpW: 35-81 $(61 \pm 23) ; n=3$.

\section{Description}

Colony brown, erect, dichotomously branching, widely and irregularly spreading, forming a threedimensional bushy structure; up to $12 \mathrm{~cm}$ in diameter and $10 \mathrm{~cm}$ high (Fig. 2A). Branches flattened, multiserial, with zooids opening on both sides, $1.9-4.1 \mathrm{~mm}$ wide (average $2.7 \mathrm{~mm} ; \mathrm{n}=39$ ); rounded at end. Autozooids oval or rhomboidal, surrounded by distinct, deep marginal groove (Fig. 2B-C). Frontal

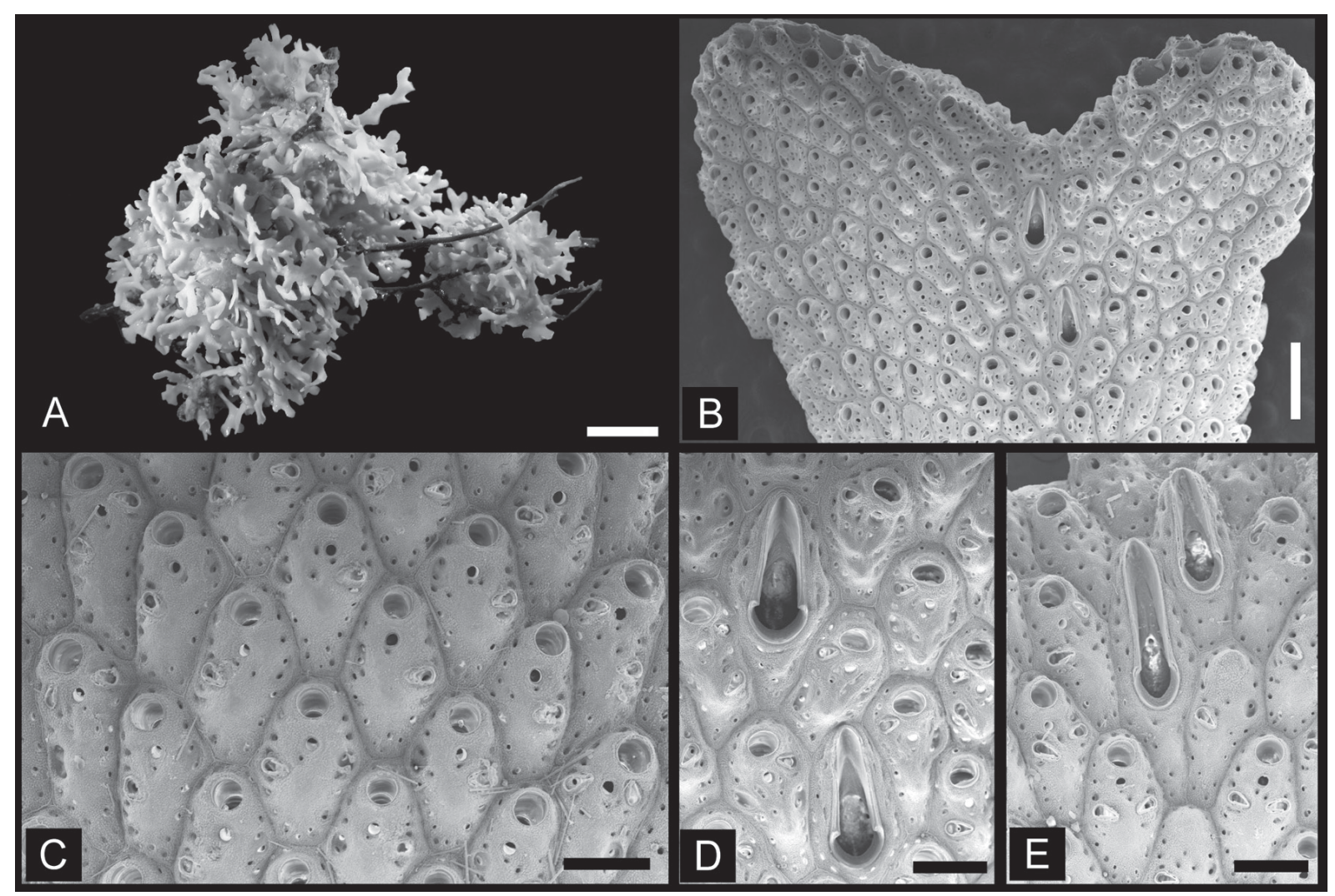

Fig. 2. Adeonella cf. lichenoides (Lamarck, 1816). A. Large, robust branching colony in Showa Emperor Collection (NSMT-BryR299, Sagami Sea). B. Distal end of branch, showing vicarious avicularia associated with a branch bifurcation (NSMT-BryR297, Sagami Sea). C. Autozooids (NSMT-BryR359, Sagami Sea). D-E. Two types of lanceolate avicularia near branch bifurcations. D. Short type (NSMTBryR297). E. Long type (NSMT-BryR359, Sagami Sea). A = optical photograph; B-E = SEM images. Scale bars: $\mathrm{A}=2 \mathrm{~cm} ; \mathrm{B}=500 \mu \mathrm{m} ; \mathrm{C}-\mathrm{E}=200 \mu \mathrm{m}$. 
shield convex, entirely covered with minute granules, with about 10 small, circular areolar pores inside each lateral margin, some additional pores in central region, and one large peristomial spiramen proximal to orifice (Fig. 2C). Peristome deep, secondary orifice circular or transversely oval. Frontal avicularia small, 1 to 4 in number, occurring near both margins on frontal shield and oriented inward (Fig. 2C) or distally (Fig. 3C). Gonozooids (Fig. 3A) present in broad region at branch bifurcations and at periphery of branches. Gonozooids larger than autozooids, with broader orifice and swollen, porous frontal shield; peristomial spiramen transversely broad, with median projection from distal margin (Fig. 3A). Vicarious avicularia occur near branch bifurcations, often replaced by gonozooids; elongate, as long as or sometimes longer than autozooids (Fig. 2B), 316-495 $\mu \mathrm{m}$ (average $390 \mu \mathrm{m}$ ) long by 124-164 $\mu \mathrm{m}$ (average $140 \mu \mathrm{m}$ ) wide $(\mathrm{n}=6)$. Vicarious avicularian chamber large (Fig. 2D-E); 425-814 $\mu \mathrm{m}$ (average $572 \mu \mathrm{m})$ long by 228-340 $\mu \mathrm{m}$ (average $274 \mu \mathrm{m})$ wide $(\mathrm{n}=6)$. Rostrum of vicarious avicularia lanceolate, acute, directed distally; variable in form and length, up to $400 \mu \mathrm{m}$ long. Large, triangular vicarious avicularia also occur along branch edges. In basal part of branches and colony, autozooids often replaced by kenozooids (Fig. 3B); 342-460 $\mu \mathrm{m}$ (average $388 \mu \mathrm{m})$ long by $167-234 \mu \mathrm{m}$ (average $192 \mu \mathrm{m})$ wide $(\mathrm{n}=4)$.

\section{Remarks}

This species was previously known as Adeonella platalea (Busk, 1854) in Japan. Lamarck (1816) first described Eschara lichenoides from the Indian Ocean, and Harmer (1957) transferred it to Adeonella. Harmer (1957) discussed the high variability in A. lichenoides and A. platalea; although he did not synonymize these species, he noted three groups of $A$. platalea based on variant forms of vicarious avicularia and mandible. Although Harmer's concept of the nature of intra- vs interspecific variation was different from that of more recent authors, Hayward (1988) restudied a syntype of Eschara lichenoides and found this specimen to be nearly identical to the paratype of A. platalea, and thus considered A. lichenoides to be a subjective senior synonym. Morphological variation within the extremely broad recorded distribution of this species from East Africa to eastern Australia, however, might indicate the presence of two or more unrecognized species.

Mawatari (1952) reported Adeona (Adeonellopsis) japonica from off Minabe and Shirahama, Wakayama Prefecture, without any description but with a photograph of a single branch in which zooids have a swollen frontal shield with a single spiramen, quite resembling Adeonella. The photograph in Mawatari (1952) may be of a branch of A. cf. lichenoides (Brz.17) in the SMBL collection.

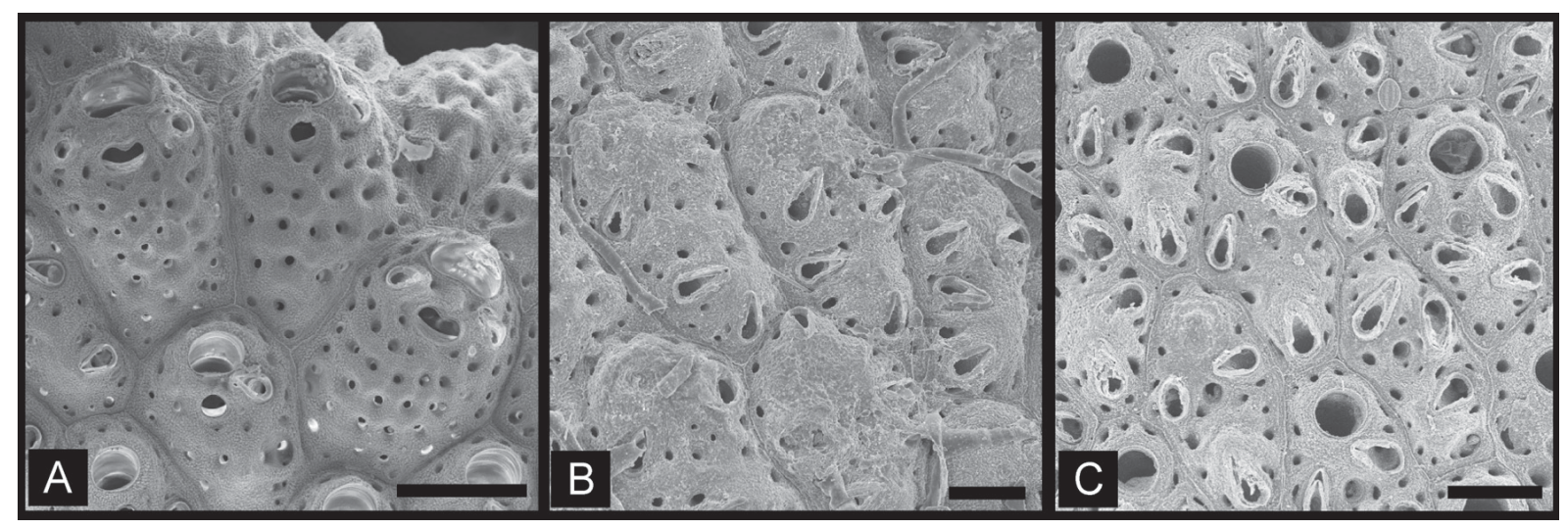

Fig. 3. Adeonella cf. lichenoides (Lamarck, 1816). A. Gonozooids at branch bifurcation (NSMT-Bry R 365, Sagami Sea). B. Kenozooids with numerous frontal avicularia (NSMT-BryR360, Sagami Sea). C. Autozooids with numerous frontal avicularia (NSMT-TeS14, Sagami Sea). SEM images. Scale bars: $\mathrm{A}, \mathrm{C}=200 \mu \mathrm{m} ; \mathrm{B}=100 \mu \mathrm{m}$. 


\section{Distribution}

Adeonella lichenoides has previously been reported from the Indo-West Pacific (Philippines, Malay Archipelago, Queensland coast, Torres Strait, northern and western coasts of Australia and Victoria, and eastward to Zanzibar and East Africa) (Hayward, 1988). In Japan, Adeonella cf. lichenoides has been collected from Sagami Bay, Sagami Sea, around the Izu Peninsula, off the Kii Peninsula, the west coast of Kyushu (Koshiki Strait), and Ogasawara, at depths of 3-328 m. Although Adeonella cf. lichenoides was not collected from the eastern part of Sagami Bay by Döderlein or Doflein, it was very abundant in the western Sagami Sea (in ES collection) such as exposed shallow rocky habitat $(3-45 \mathrm{~m})$ at the southernmost part of the Izu Peninsula (Hirose et al. 2012).

Adeonella jahanai sp. nov.

urn:1sid:zoobank.org:act:36CA23B8-7008-4562-9E24-D29AD412BE0C

Figs $4-5$

\section{Diagnosis}

Colony dichotomously branching; branches narrow, about $1.2-2.5 \mathrm{~mm}$ wide. Autozooids oval or hexagonal, distinct, delineated by deep groove. Frontal shield entirely covered with minute granules, with more than 10 circular or slit-like areolar pores. Peristome deep, secondary orifice circular, primary

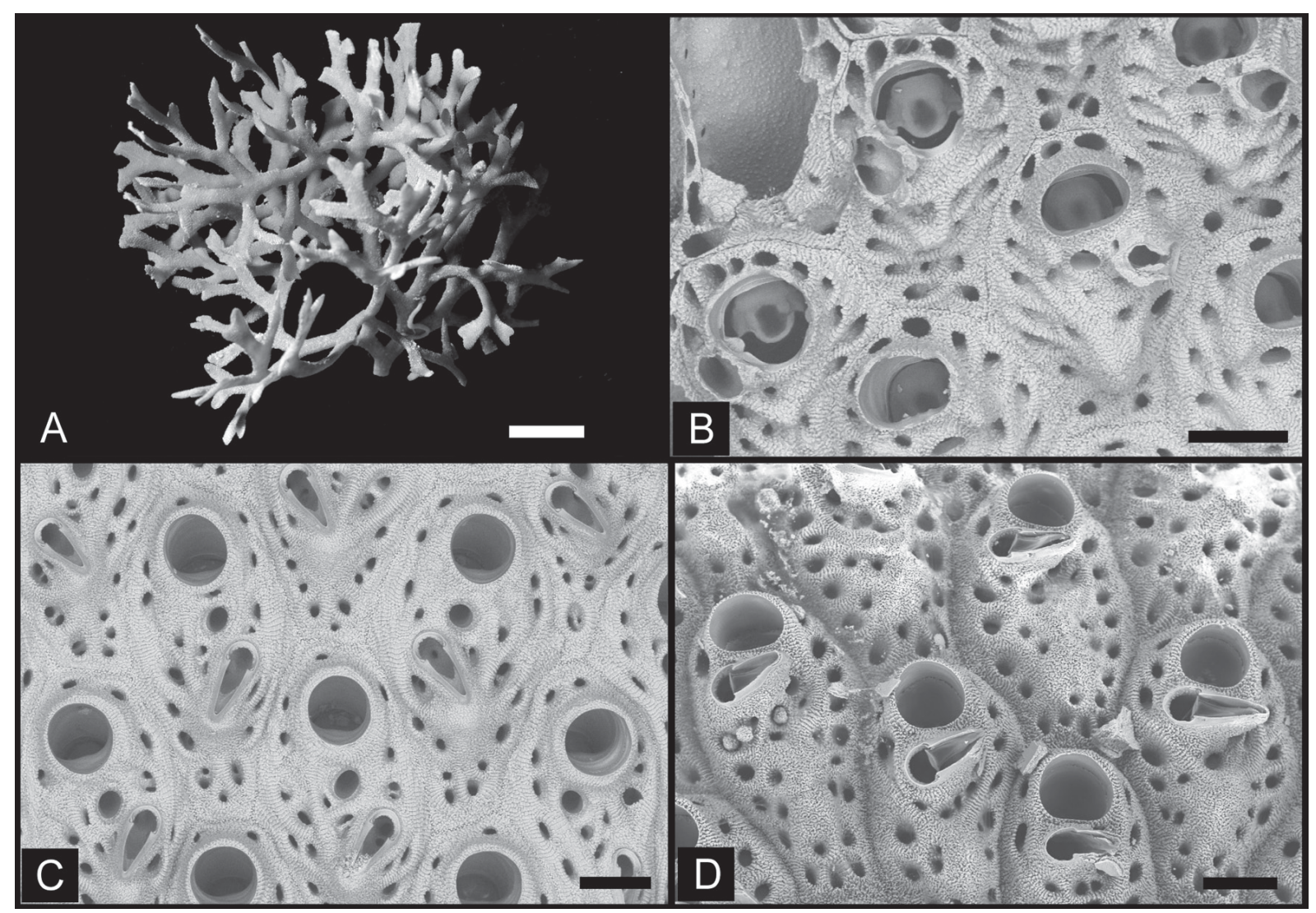

Fig. 4. Adeonella jahanai sp. nov. A. Holotype colony with narrow branches (NSMT-Te1050, Okinawa). B. Young autozooids at distal end of branch, showing primary orifices NSMT-Te889. C. Autozooids with elongate frontal avicularia (NSMT-Te889, Okinawa). D. Young autozooids with a single triangular avicularium abutting the proximal margin of the peristome (NSMT-Te889, Okinawa). A = optical photograph; B-D = SEM images. Scale bars: A $=1 \mathrm{~cm}$; B-D $=100 \mu \mathrm{m}$. 
orifice with a deep and broadly U-shaped sinus, condyles short but broad and blunt. Many irregular frontal pores in central region. Frontal avicularia triangular, narrow, elongate; in center or at proximal margin of frontal shield, directed inward or proximally. Another frontal avicularium abuts proximal margin of peristome, rostrum slightly projected, directed laterally. Large, triangular vicarious avicularia

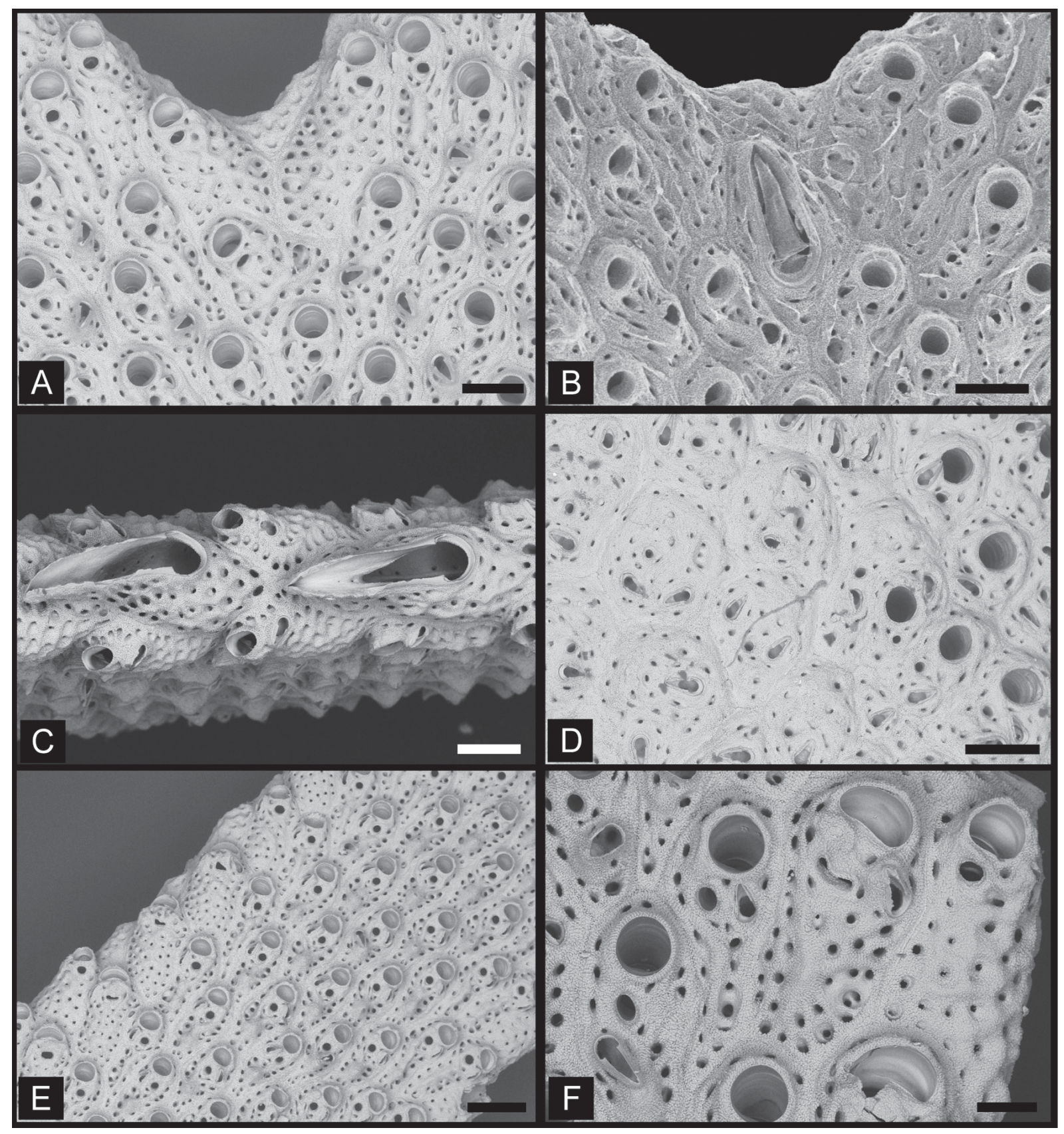

Fig. 5. Adeonella jahanai sp. nov. A. Branch bifurcation lacking vicarious avicularaia (NSMTTe889, Okinawa). B. Branch bifurcation with vicarious avicularium (NSMT-Te749, off Yakushima). C. Vicarious avicularia on side of branch (NSMT-Te889, Okinawa). D. Old part of branch showing autozooids and kenozooids (NSMT-Te889, Okinawa). E. Gonozooids at periphery of branch (NSMTTe889, Okinawa). F. Gonozooid at periphery of branch (NSMT-Te889, Okinawa). SEM images. Scale bars: $A-D=200 \mu \mathrm{m} ; \mathrm{E}=300 \mu \mathrm{m} ; \mathrm{F}=100 \mu \mathrm{m}$. 
present along branch margins and at bifurcations. Gonozooids slightly larger than autozooids, with porous frontal shield; secondary orifice broad, with slightly convex proximal margin.

\section{Etymology}

The species is named after Mr. Yoshikazu Jahana, the fisherman who collected the holotype specimen off Motobu, Okinawa.

\section{Material examined}

\section{Holotype}

JAPAN: large colony collected 19 Mar. 2014 north of Motobu, Okinawa, 26² 42'54.72" N, 127²53'25.62" E, $60 \mathrm{~m}$ depth, by basket net (NSMT-Te1050).

\section{Paratypes}

JAPAN: several branches, same collection data as for holotype (NSMT-Te889); single small branch collected 25 May 2009 southwest of Yakushima, 3005'08.40" N, 13004'43.20" E, 87-88 m depth, by dredge, T/V Toyoshio-maru (NSMT-Te749); many branches collected 23 May 2010 south of Nagannu Island, Okinawa, 26 ${ }^{\circ} 14^{\prime} 37.80^{\prime \prime} \mathrm{N}, 127^{\circ} 32^{\prime} 28.20^{\prime \prime} \mathrm{E}, 37-46 \mathrm{~m}$ depth, by dredge, T/V Toyoshiomaru (NSMT-Te775); some fragments collected 21 May 2011 south of Nagannu Island, Okinawa, $26^{\circ} 14^{\prime} 39.00^{\prime \prime} \mathrm{N}, 127^{\circ} 32^{\prime} 55.20^{\prime \prime} \mathrm{E}$ to $26^{\circ} 14^{\prime} 43.20^{\prime \prime} \mathrm{N}, 127^{\circ} 31^{\prime} 48.60^{\prime \prime} \mathrm{E}, 47-52 \mathrm{~m}$ depth, by dredge, T/V Toyoshio-maru (NSMT-Te751); some fragments collected 27 May 2012 south of Nagannu Island, Okinawa, $26^{\circ} 14^{\prime} 34.68^{\prime \prime} \mathrm{N}, 127^{\circ} 32^{\prime} 1.26^{\prime \prime}$ E to $26^{\circ} 14^{\prime} 36.66^{\prime \prime} \mathrm{N}, 127^{\circ} 31^{\prime} 54.18^{\prime \prime} \mathrm{E}, 52-54 \mathrm{~m}$ depth, by dredge, T/V Toyoshio-maru (NSMT-Te804); some fragments collected 27 May 2012 east of Maeshima Island, Okinawa, $26^{\circ} 11^{\prime} 41.40^{\prime \prime} \mathrm{N}, 127^{\circ} 27^{\prime} 20.34^{\prime \prime} \mathrm{E}$ to $26^{\circ} 11^{\prime} 39.90^{\prime \prime} \mathrm{N}, 127^{\circ} 27^{\prime} 18.36^{\prime \prime} \mathrm{E}, 55-57 \mathrm{~m}$ depth, by dredge, T/V Toyoshio-maru (NSMT-Te805); some fragments collected 28 May 2012 south of Iejima Island, Okinawa, 263' $14.28^{\prime \prime} \mathrm{N}, 17^{\circ} 41^{\prime} 47.52^{\prime \prime}$ E to $26^{\circ} 39^{\prime} 19.38^{\prime \prime} \mathrm{N}, 127^{\circ} 41^{\prime} 52.98^{\prime \prime} \mathrm{E}, 94-95 \mathrm{~m}$ depth, by dredge, T/V Toyoshio-maru (NSMT-Te806).

\section{Measurements}

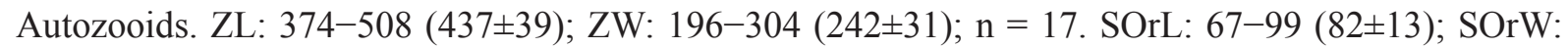

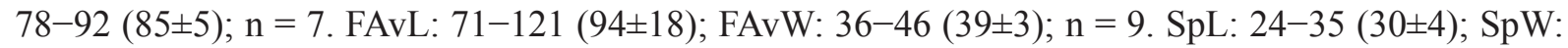
$24-32(28 \pm 2) ; \mathrm{n}=7$.

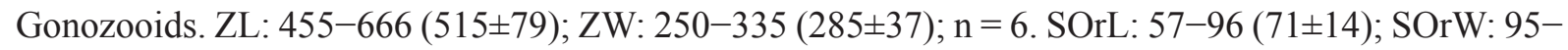
$128(103 \pm 12) ; \mathrm{n}=6$. SpL: 19-27 (23 \pm 3$) ;$ SpW: 38-49 (42 \pm 4$) ; \mathrm{n}=6$.

\section{Description}

Colony brown, erect, dichotomously branching, widely and irregularly spreading, forming a bushy three-dimensional structure; up to $6 \mathrm{~cm}$ in diameter and $5 \mathrm{~cm}$ high (Fig. 4A). Branches slender, nearly uniform in width, flattened, multiserial, with zooids opening on both sides, 1.1-2.4 mm wide (average $1.7 \mathrm{~mm} ; \mathrm{n}=34)$; rounded at tip. Autozooids oval or hexagonal, surrounded by a distinct marginal groove (Fig. 4C-D). Frontal shield convex, entirely covered with minute granules, with about 10-20 small, circular or slit-like areolar pores inside each lateral margin, many additional irregular pores in central region, and one large peristomial spiramen proximal to orifice (Figs 4C, 5B). Peristome deep, secondary orifice circular or transversely oval. Primary orifice deeply immersed in peristome, visible only in early ontogenetic zooids; with a deep and broadly U-shaped sinus and conspicuous condyles (Fig. 4B), 59-78 $\mu \mathrm{m}$ (average $72 \mu \mathrm{m})$ long by $71-90 \mu \mathrm{m}$ (average $82 \mu \mathrm{m}$ ) wide $(\mathrm{n}=5$ ). Frontal avicularia triangular, narrow, elongate, single or paired, occurring in center of frontal shield or toward proximal margin and oriented proximally or inward (Fig. 4C). Another frontal avicularium abutting the proximal margin of peristome, rostrum slightly projected, directed laterally (Fig. 4D). Gonozooids present at periphery of branches (Fig. 5E). Gonozooids larger than autozooids, with broader orifice and porous frontal shield; 
peristomial spiramen transversely broad, with median projection from distal margin (Fig. 5F). Vicarious avicularia rarely present near branch bifurcations, often lacking; elongate, as long as or sometimes longer than autozooids (Fig. 5B), 384-617 $\mu \mathrm{m}$ (average $500 \mu \mathrm{m}$ ) long by 126-158 $\mu \mathrm{m}$ (average $142 \mu \mathrm{m}$ ) wide $(\mathrm{n}=2)$. Rostrum of vicarious avicularia lanceolate, acute, directed distally; up to $410 \mu \mathrm{m}$ long $(348 \pm 97, \mathrm{n}=2)$. Large vicarious avicularia also occur along branch edges (Fig. 5C), up to $579 \mu \mathrm{m}$ long $(572 \pm 9, \mathrm{n}=2)$ by $142 \mu \mathrm{m}$ wide $(139 \pm 5, \mathrm{n}=2)$. In basal part of branches and colony, autozooids are often replaced by kenozooids (Fig. 5D); 380-416 $\mu \mathrm{m}$ (average $400 \mu \mathrm{m}$ ) long by $252-304 \mu \mathrm{m}$ (average $284 \mu \mathrm{m})$ wide $(\mathrm{n}=5)$.

\section{Remarks}

Adeonella jahanai sp. nov. resembles A. lichenoides in having a granulated frontal shield, and in the location of the small, triangular frontal avicularium, but differs from the latter in having markedly narrower branches, numerous slit-like areolar pores on the frontal shield, elongate frontal avicularia, and the frontal avicularia directed proximally. Autozooids of Adeonella jahanai sp. nov. also differ from A. lichenoides in having another frontal avicularium, triangular, slightly projected, directing laterally, abutting the proximal margin of the peristome. Adeonella jahanai sp. nov. resembles A. extensa Harmer, 1957 in having narrow branches, gonozooids along the margin of branches, and slightly longer frontal avicularia, and in generally lacking vicarious avicularia near branch bifurcations, but differs from the latter in the direction of the frontal avicularia, and in having gonozooids with a non-tubular peristome, with the peristomial spiramen being very closely situated to the secondary orifice.

\section{Distribution}

Japan: Nansei Islands (near Yakushima and west of Okinawa), at depths of 37-95 m.

Genus Adeonellopsis MacGillivray, 1886

Adeonellopsis arculifera (Canu \& Bassler, 1929)

Fig. 6

Adeona arculifera Canu \& Bassler, 1929: 377, pl. 52, figs 1-2.

Adeonellopsis arculifera - Harmer 1957: 800, text-figs 82C, 84A, pl. LIII, figs 13-14.

Adeonella subsulcata - Thornely 1905: 125.

\section{Material examined}

JAPAN: many branches collected from Hirase, southwest of Yakushima Island, 87-88 m depth (NSMTTe781, Te783, Te784, Te785, Te786, Te787, Te788, Te789); single colony collected from South of Nagannu Island, 47-52 m depth (NSMT-Te782).

\section{Measurements}

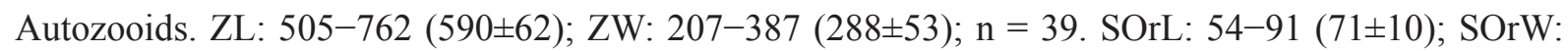

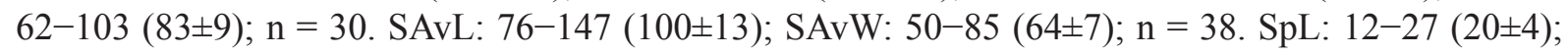
SpW: $16-25(20 \pm 3) ; \mathrm{n}=28$.

\section{Description}

Colony small, slender, dichotomously branching (Fig. 6A); yellowish white. Branches subcylindrical or flat (Fig. 6B); slender, on average $1 \mathrm{~mm}$ wide $(0.9-1.3 \mathrm{~mm}, \mathrm{n}=8)$, multiserial, zooids opening on both sides. Zooids oval, boundaries indistinct, delineated by shallow groove and opposing single rows of tiny, irregular areolar pores (Fig. 6D). Frontal shield smooth, or finely granulate and slightly 
wrinkled. Zooids raised distally towards a low peristomial rim; primary orifice D-shaped, with straight or convex proximal margin; secondary orifice broader than long. Spiramen small, uniporous, circular, situated close to center of frontal shield proximal to orifice, often in depressed frontal zone (Fig. 6C).

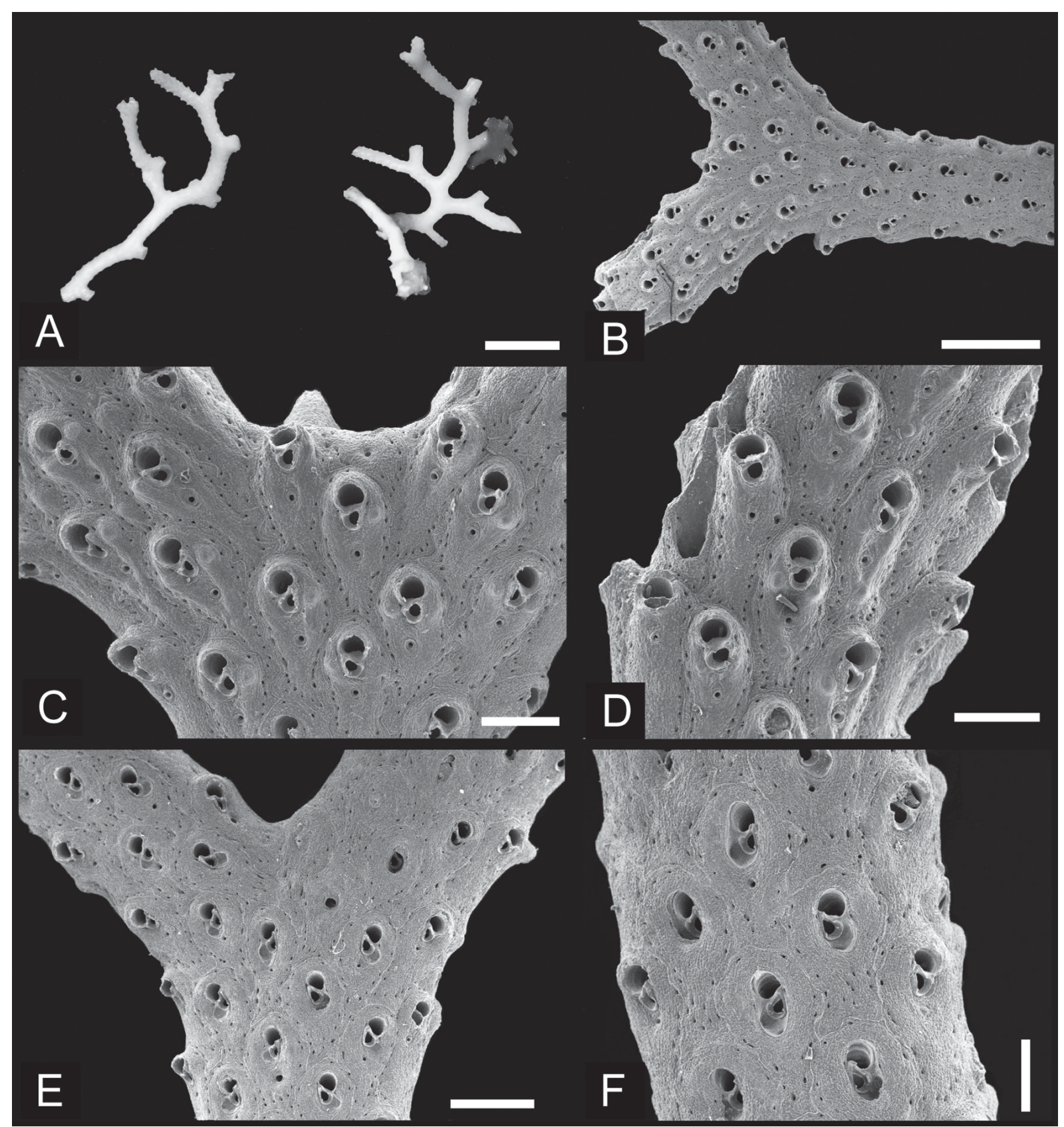

Fig. 6. Adeonellopsis arculifera (Canu \& Bassler, 1929). A. Colonies collected SW of Yakushima Island (NSMT-Te789). B. Branch showing crenulate periphery (NSMT-Te781). C. Enlargement of bifurcation showing autozooids with oblique avicularium and single small spiramen (NSMT-Te781). D. Young autozooids showing peristomial rim and single small spiramen (NSMT-Te781). E. Old part of branch, showing various stages in formation of kenozooids (NSMT-Te781). F. Old part of branch, showing autozooids with depression containing avicularium and spiramen (NSMT-Te781). A = optical photograph; B-F $=$ SEM images. Scale bars: $A=5 \mathrm{~mm}$; B $=1 \mathrm{~mm}$; $\mathrm{C}-\mathrm{D}=300 \mu \mathrm{m}$; E $=500 \mu \mathrm{m} ; \mathrm{F}=$ $250 \mu \mathrm{m}$. 
Suboral avicularium abutting proximal margin of peristome, smaller in area than secondary orifice, rostrum slightly raised and sometimes hooked distally, slightly curved toward distal side, directed distolaterally; no crossbar; mandible equilaterally triangular (Fig. 6C). No other types of avicularia observed. Autozooids distal to branch bifurcations elongate, sometimes bearing up to three umbonate bosses $47-76 \mu \mathrm{m}$ in diameter (average $61 \mu \mathrm{m}, \mathrm{n}=18$ ), on one or both sides proximolateral to orifice and toward proximal end of frontal shield (Fig. 6D). Older autozooids in basal part of branch broad, irregular in outline; zooidal boundaries indistinct; frontal shield heavily secondarily calcified; spiramen often lacking; suboral avicularium lies in depression in thickened frontal shield (Fig. 6F). Rarely, kenozooids occur at basal bifurcations (Fig. 6E); same size as autozooids. Gonozooids not found.

\section{Remarks}

Canu \& Bassler (1929) originally described Adeona arculifera from Jolo and Sulade Islands, Sulu Archipelago, Philippines, on the basis of the single spiramen, although the branched colony resembles the condition in Adeonellopsis. Harmer (1957) then transferred the species to Adeonellopsis on the basis of the operculum, which is not widely sinuate. Adeonellopsis arculifera resembles A. subsulcata (Smitt, 1873) in the arrangement of the suboral avicularia but differs from the latter in having a circular spiramen in the center of the frontal shield.

\section{Distribution}

Adeonellopsis arculifera has previously been reported from the Philippines, Indonesia, and the Indian Ocean, at depths of 38-53 m. In Japan, it has been detected only in the southwestern region, from Okinawa and near Yakushima Island, at depths of 47-88 m. Although this is the first Recent record for Japan, Hayami (1971) reported the species from the Pliocene Shinzato Tuff on Okinawa Island.

Adeonellopsis japonica (Ortmann, 1890)

Figs 7-9, 10A

Adeonella japonica Ortmann, 1890: 54, pl. 4, fig. 11.

Adeonella japonica - Okada 1920: 628, text fig. 6, pl. 8, fig. 9. — Okada \& Mawatari 1935: 140, pl. XI, fig. 2. — Okada \& Mawatari 1938: 460.

Adeona japonica - Canu \& Bassler 1927: 34. - Mawatari 1952: 285 [figured specimen is not A. japonica].

Adeonellopsis parvipuncta - Harmer, 1957: 798, pl. LIII, fig. 16.

Adeonellopsis japonica - Cheetham et al. 1980: 335-369. — Hirose et al. 2012: 121-136, fig. 9.2.

non Adeonellopsis parvipuncta MacGillivray, 1886: 135, pl. II, fig. 4a.

\section{Material examined}

Lectotype [designated herein]

JAPAN: branched colony, Sagami Bay, 1882, 111-277 m depth, collected by L. Döderlein, MZS 3-3 (SEM specimen NSMT-Te741).

Paralectotypes [designated herein]

JAPAN: branched colonies, Jogashima, 1882, 185-370 m depth, collected by L. Döderlein, MZS 3-4 (SEM specimen NSMT-Te742); branched colony, Sagami Bay, 1882, collected by L. Döderlein, MZS 3-1; branched colonies, Sagami Bay, MZS 3-2 (SEM specimen NSMT-Te739), "15 August 1889/29 July 1890, 111 m depth, southeast of Jogashima, Sagami Bay" is written on a small label, but the collector and the date are unclear). 


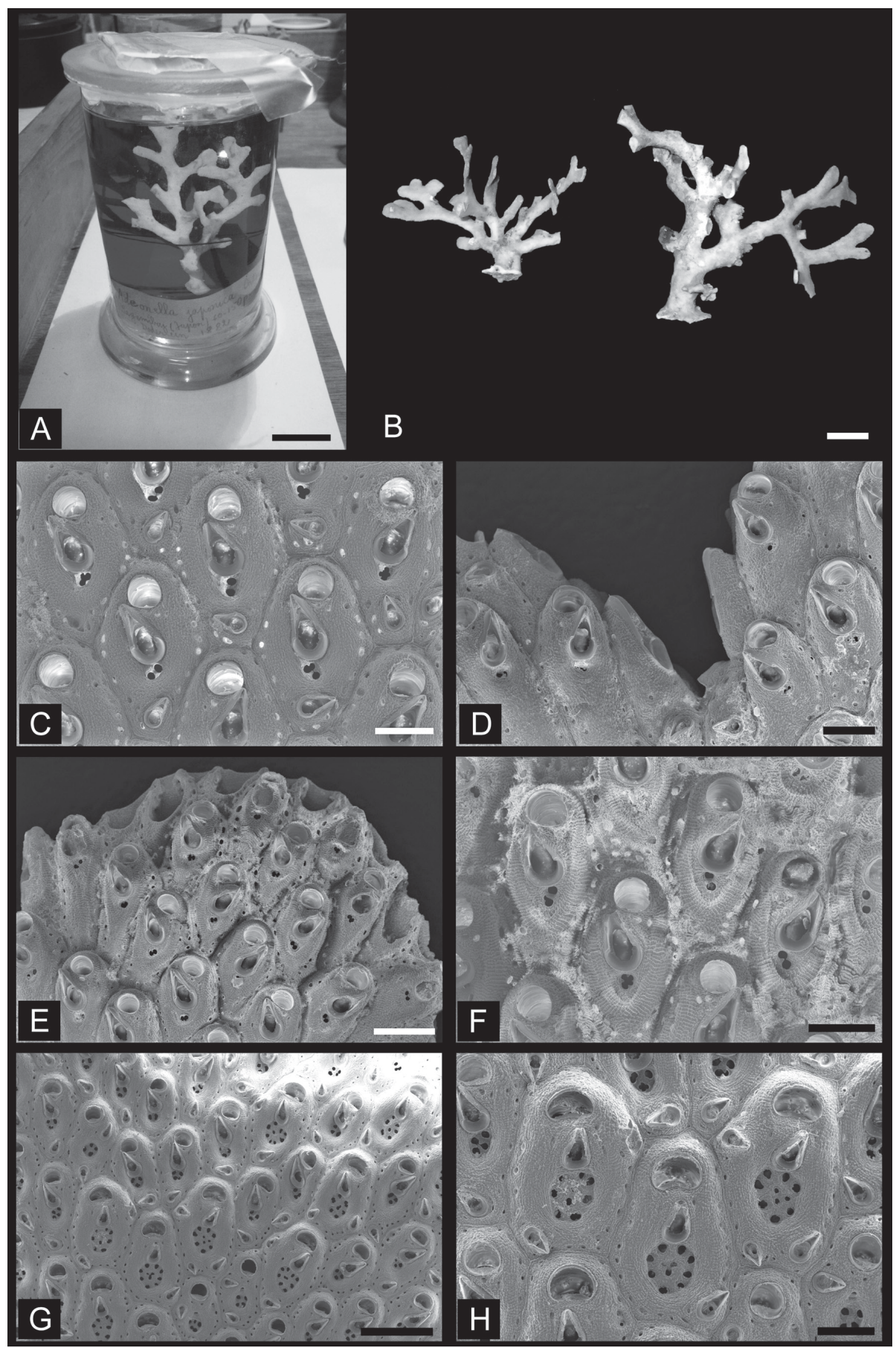

Fig. 7. Adeonellopsis japonica (Ortmann, 1890). A. Lectotype from among Ortmann's specimens in the Döderlein Collection (MZS 3-3). B. Colonies collected at Otsuchi (NSMT-Te760). C. Autozooids with large suboral avicularium and biporous spiramen (NSMT-Te741, from lectotype, MZS 3-3). D. Lateral vicarious avicularia at branch bifurcation (NSMT-Te741, from lectotype, MZS 3-3). E. Young autozooids at distal end of branch (NSMT-Te741, from lectotype, MZS 3-3). F. Young autozooids, with biporous spiramen surrounded by thick, swollen rim bearing rows of granulation (NSMT-Te741, from lectotype, MZS 3-3). G. Autozooids and gonozooids at branch bifurcation (NSMT-Te742, from paralectotype MZS 3-4). H. Gonozooids showing large multiporous spiramen (NSMT-Te742, from paralectotype MZS 3-4). A-B = optical photographs; $\mathrm{C}-\mathrm{H}=\mathrm{SEM}$ images. Scale bars: $\mathrm{A}=2 \mathrm{~cm} ; \mathrm{B}=1 \mathrm{~cm} ; \mathrm{C}-\mathrm{D}, \mathrm{F}$, $\mathrm{H}=200 \mu \mathrm{m} ; \mathrm{E}=300 \mu \mathrm{m} ; \mathrm{G}=500 \mu \mathrm{m}$. 


\section{Other material examined}

JAPAN: eastern side of Sagami Bay (NSMT-BryR36, Bry R71, Bry R193, BryR206, BryR225, BryR254, BryR255, BryR259, BryR260, BryR261, BryR277, all in Emperor Showa collection); eastern side of Sagami Bay, collected by NSMT (NSMT-TeS15 to TeS18); NE off Ohakozaki, Otsuchi, collected by

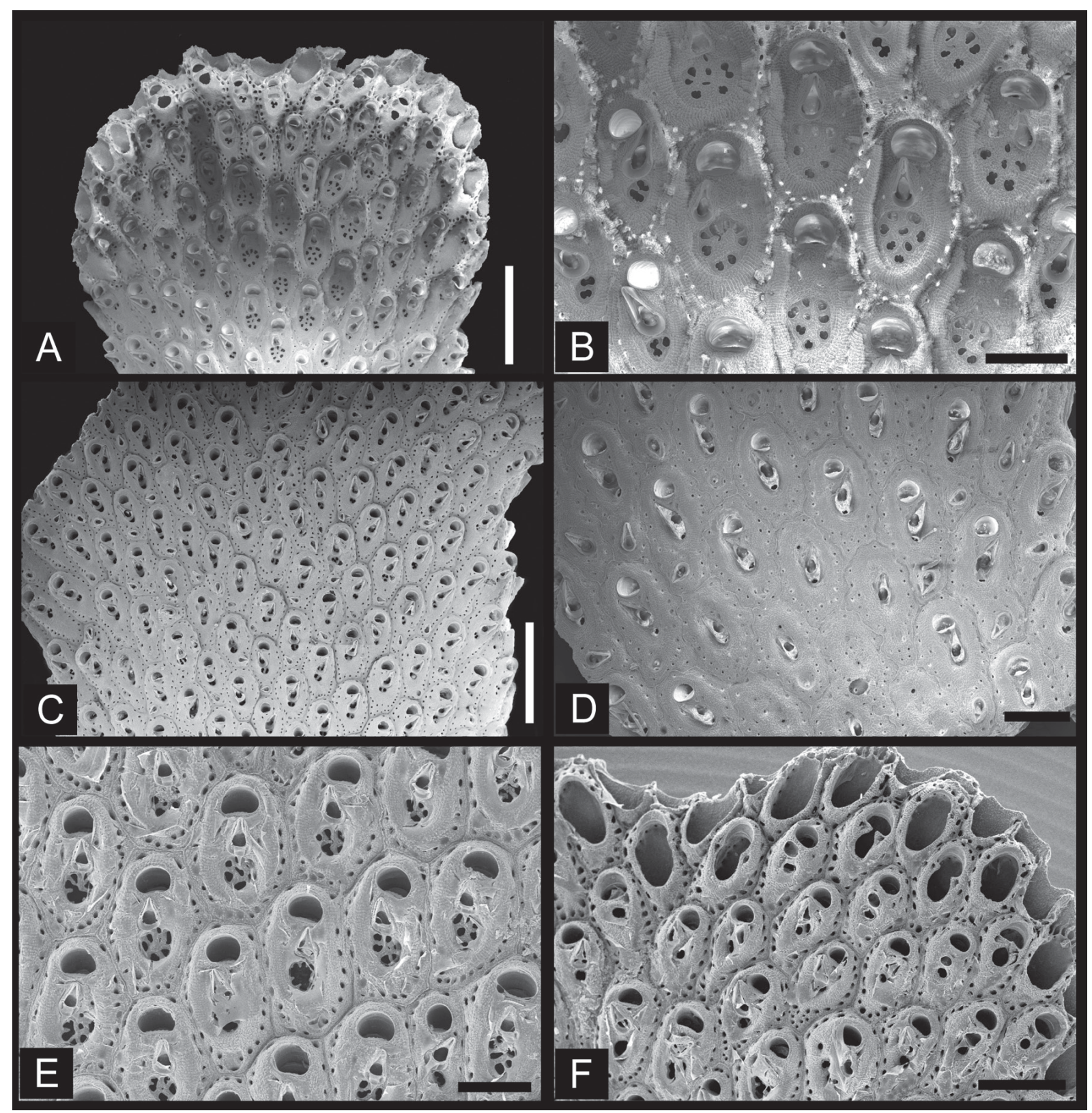

Fig. 8. Adeonellopsis japonica (Ortmann, 1890). A. Distal end of branch just starting to bifurcate, showing young autozooids and gonozooids (NSMT-BryR277). B. Enlargement of young gonozooids, showing peripheral rim with rows of granulation perpendicular to margin, and large multiporous spiramen (NSMT-BryR277). C. Autozooids in middle of branch, showing immersed spiramen (NSMTBry R 193). D. Basal part of branch, showing autozooids, and some kenozooids with closed orifice (NSMT-BryR36). E. Young gonozooids, showing distinct marginal pores and multiporous spiramen (NSMT-Te758). F. Distal end of branch, showing autozooid formation (NSMT-Te758). SEM images. Scale bars: A, C $=1 \mathrm{~mm}, \mathrm{~B}, \mathrm{D}-\mathrm{E}=300 \mu \mathrm{m} ; \mathrm{F}=500 \mu \mathrm{m}$. 
M. Hirose (NSMT-Te758, Te759, Te760); west-southwest of Jogashima, Sagami Bay, collected by H. Koutsuka and M. Hirose (NSMT-Te795, Te798); south of Kanae-zaki, Tosashimizu, Kochi (NSMTTe1051); Seto, Kii Peninsula, Aug. 1936, probably specimen studied by Okada \& Mawatari (1938) (SMBL-Brz.17, some fragments NSMT-Te1052); Pacific Ocean, off Honshu Island, 7 May 1900, Albatross Station D.3704, 107-275 m depth (USNM PAL 271600A-D).

HAWAI'I: off Oahu Island, Albatross Station D.3916, 549-605 m depth, collected 6 May 1902 (USNM PAL 271601); south coast of Oahu Island, Albatross Station D.3916 (USNM RB 8450).

\section{Measurements}

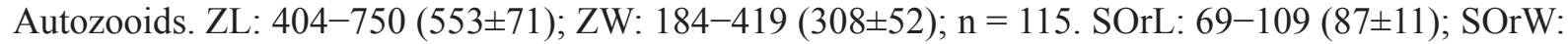

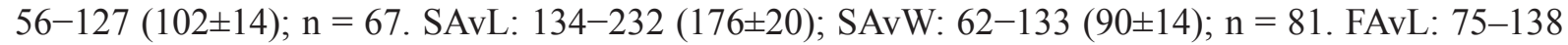

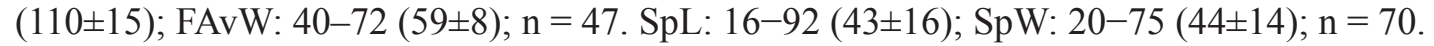

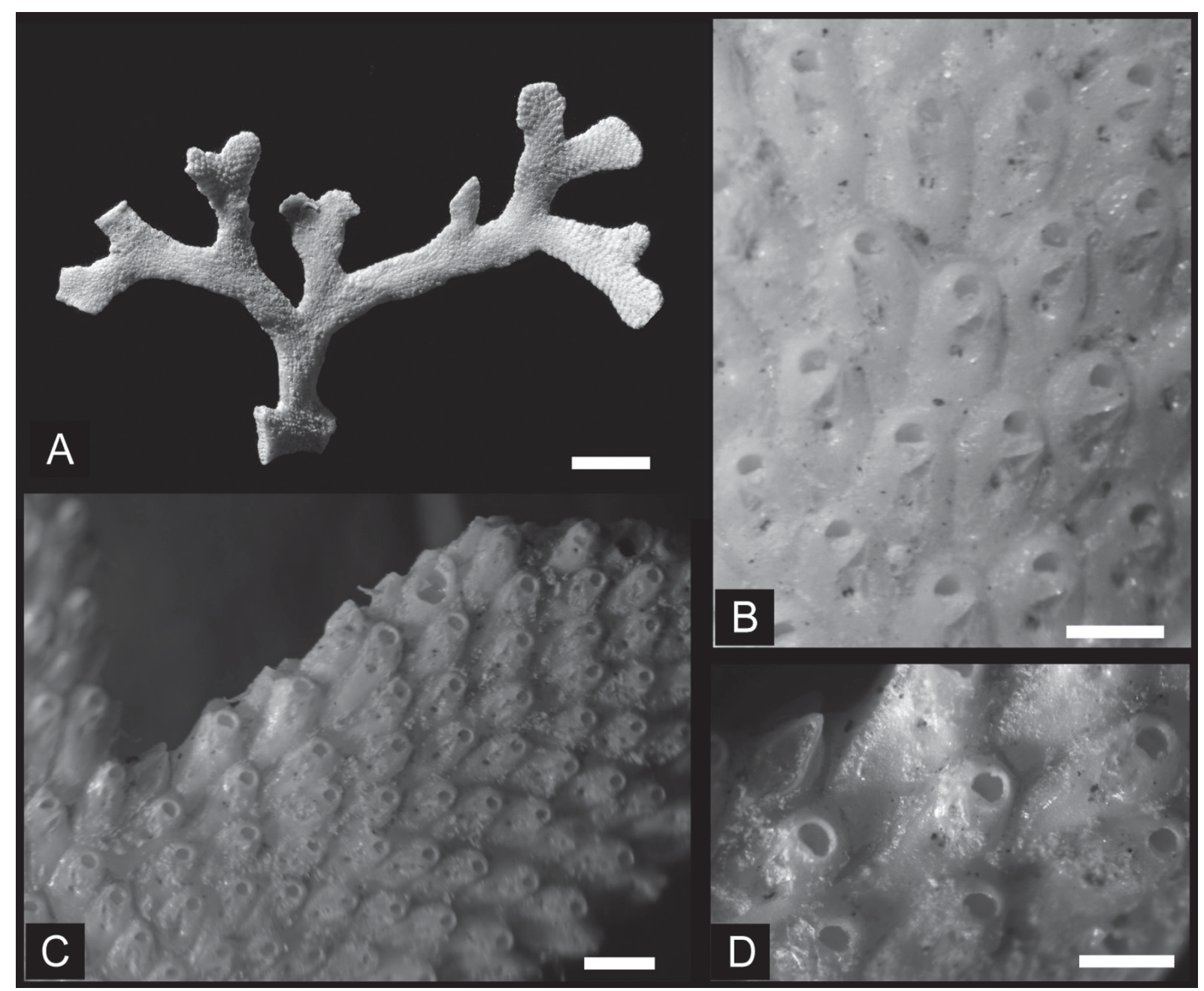

Fig. 9. Adeonellopsis japonica (Ortmann, 1890). A. Colony collected at Albatross Station D, off Oahu Island, Hawaii (USNM 271601). B. Autozooids of Hawaii specimen, showing suboral avicularia and biporous spiramen (USNM 271601, Hawaii). C. Autozooids and lateral vicarious avicularia at a branch bifurcation (USNM 271601 paper box, Hawaii). D. Enlargement of lateral vicarious avicularia at branch bifurcation (USNM 271601 paper box, Hawaii). A = optical photograph; B-D = photomicrographs. Scale bars: $A=5 \mathrm{~mm} ; \mathrm{B}, \mathrm{D}=300 \mu \mathrm{m} ; \mathrm{C}=500 \mu \mathrm{m}$. 


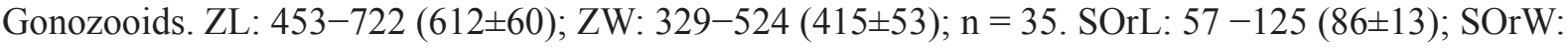

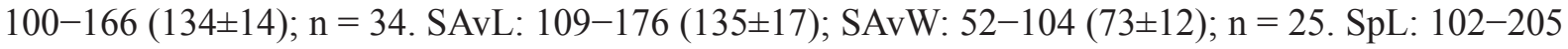
(146 \pm 24$) ;$ SpW: 98-174 (134 \pm 21$) ; n=33$.



\section{Description}

Colony yellowish brown, erect, dichotomously branching, irregularly spreading; up to $10 \mathrm{~cm}$ high (Fig. 7A). Branches flattened (Figs 7B, 9A), multiserial, with zooids opening both sides, rounded at end; 1.6-4.6 mm wide (average $2.8 \mathrm{~mm} ; \mathrm{n}=27$ ). Autozooids oval or hexagonal, outlined by a distinct deep marginal groove (Figs 7C, 8C, 9B), with 6-9 small pores along each lateral margin and two or three small frontal pores just proximal to orifice. Frontal shield umbonuloid (Fig. 10A). Young autozooids at growing margin of branch have concave frontal shields surrounded by broad, swollen rim with rows of granulation arranged perpendicular to margin (Fig. 7E-F); rim width 41-76 $\mu \mathrm{m}$ (average $57 \mu \mathrm{m})(\mathrm{n}$ $=31$ ). Mature frontal shield convex, entirely covered with minute granules. Spiramen abuts proximal end of suboral avicularium; subdivided into two or three openings separated by narrow septa, or lobate due to incomplete septa (Fig. 7C); with increased calcification, sometimes appearing as single opening (Fig. 7D); reduced in size during ontogeny, associated with depression of avicularian rostrum, sometimes occluded (Figs 7D, 8D). Secondary orifice nearly circular (Fig. 7C) or broader than long (Figs 7D, 8C); peristomial rim lacking; primary orifice submerged deep in peristome. Large, suboral avicularium in center of frontal shield, extending from spiramen to proximolateral corner of orifice, or nearly so, usually pointing distolaterally (Figs 7C, F, 9B); rostrum slightly raised distally, not hooked; mandible elongate-triangular; no crossbar. Additional smaller frontal avicularium often present near proximal end of zooid; identical in form to suboral avicularium; pointing in any direction (Fig. 7C). Gonozooids occur at branch bifurcations (Fig. 8B, E); larger than autozooids, with broader, slightly curving orifice; bearing suboral avicularium; smaller frontal avicularia either lacking (Fig. 8B, E) or up to three per zooid (Fig. 7G-H). Spiramen large, roughly circular in outline, divided into $6-10$ pores (Figs $7 \mathrm{G}-\mathrm{H}, 8 \mathrm{~B}$ ). Spiramen lacking marginal denticles in both autozooids and gonozooids (Figs 7C, F, 8E), although incomplete septa may appear as denticles. Vicarious avicularia at branch margins (Figs 7D, 8A, 9C-D) smaller than autozooids; triangular, with mandible directed distally. Basal part of branch consists of kenozooids with secondary orifice occluded by secondary calcification (Fig. 8D); about same size as autozooids, 486-631 $\mu \mathrm{m}$ long (average $541 \mu \mathrm{m})$ by $199-351 \mu \mathrm{m}$ wide (average $314 \mu \mathrm{m})(\mathrm{n}=11)$. Kenozooids also



Fig. 10. Interior frontal shield. A. Adeonellopsis japonica (Ortmann, 1890) (NSMT-Te1052). B. A. parvirostrum sp. nov. (NSMT-Te807). Arrowheads indicate ring scar. SEM images. Scale bars: A $=50 \mu \mathrm{m}$; $\mathrm{B}=25 \mu \mathrm{m}$. 
bearing several small avicularia budded from areolae, near proximal margin of zooid, associated with other marginal pores (Fig. 8D), 101-152 $\mu \mathrm{m}$ long (average $121 \mu \mathrm{m}$ ) by $47-75 \mu \mathrm{m}$ wide (average $59 \mu \mathrm{m}$ ) $(n=15)$.

\section{Remarks}

Ortmann (1890) first described Adeonellopsis japonica as Adeonella japonica, based on Döderlein's specimens from Sagami Bay. Hayward (1988) discussed this species in his revision of Adeonella, though he did not examine Ortmann's material; he argued that Adeonella japonica almost certainly belongs in Adeonella because of the elongate avicularia along the edge of the branches, as described by Ortmann. However, the frontal shield of $A$. japonica is umbonuloid, rather than the lepralioid frontal shield characteristic of Adeonella; therefore, A. japonica clearly belongs in Adeonellopsis. Harmer (1957) reported a Japanese adeonid species resembling Adeonellopsis parvipuncta MacGillivray (1886), which has two kinds of spiramina: a small, undivided, slightly denticulate single pore, or a much larger pore region comprising many pores. These features of the spiramen completely correspond to the spiramina of autozooids and gonozooids in A. japonica. Harmer (1957) noted that a few zooids in the middle of the branches have a larger spiramen, which is the condition of gonozooids in A. japonica. Furthermore, his sketch of the larger zooid also indicates a broader, slightly curved orifice. I thus consider Harmer's A. parvipuncta to be a synonym of $A$. japonica.

\section{Distribution}

Japan: Sagami Bay, Sagami Sea, Suruga Bay, Kii Peninsula, Kouchi, and Otsuchi; 48.7-493 m depth. The current species has also been collected from Hawaii (off Oahu Island), 549-605 m depth, by the R/V Albatross (USNM 271601, IZ cat 8450; RB 8450) (Fig. 9).

Okada \& Mawatari (1938) reported this species from Kata, Seto, and off Wakayama, around the Kii Peninsula; the specimens in the SMBL include both A. japonica and Adeonella cf. lichenoides. Mawatari (1952) also reported A. japonica from Wakayama Prefecture, without a description, but with an illustration (pl. XII, fig. 1), which apparently shows proximally swollen zooids and the absence of suboral avicularia, and is more similar to A. cf. lichenoides. Adeonellopsis japonica is one of the common erect species in the Sagami Sea (Hirose et al. 2012).

Adeonellopsis pentapora Canu \& Bassler, 1929

Fig. 11

Adeonellopsis pentapora Canu \& Bassler, 1929: 382, pl. 53, figs 1-5.

Adeonella tuberculata - Ortmann 1890: 53, pl. 4, figs 9a-b. — Okada 1923: 231. — Kataoka 1961: 264, pl. XXXVII, fig. 2.

Adeonellopsis pentapora - Sakakura 1935: 115. — Kataoka 1961: 264, pl. XXXII, fig. 10.

Adeonellopsis yarraensis - Harmer 1957: 799, pl. LIII, figs 18-19 [in part]. — Hirose 2010: 52, pl. 89, figs A-D.

\section{Material examined}

JAPAN: colony in Döderlein Collection at MZS, from Sagami Bay, 1882 (MZS2-1, MZS2-2; SEM specimen NSMT-Te748); colonies from east side of Sagami Bay and Sagami Sea, collected by NSMT (NSMT-TeS19, TeS20, TeS21, TeS22); specimens from off Ohakozaki, Otsuchi, 70-77 m depth (NSMTTe761, Te762, Te765, Te766); Ariake Sea (NSMT-Te767, Te769); Wakasa Bay, Sea of Japan, 70-85.7 m depth (NSMT-Te800); off Shimoda (NSMT-Te892); near Yakushima and Tanegashima, 108-122 m depth (NSMT-Te763, Te764); off Iejima Island, 94-95 m depth (NSMT-Te801); Ogasawara, 136-141 m depth (NSMT-Te768). 


\section{Measurements}

Autozooids. ZL: 337-572 (434 \pm 54$)$; ZW: 227-367 (291 \pm 35$)$; $\mathrm{n}=34$. SOrL: $42-95$ (58 \pm 10$)$; SOrW:

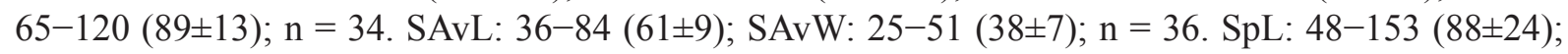
SpW: 43-111 (75 18$) ; \mathrm{n}=37$.



Fig. 11. Adeonellopsis pentapora Canu \& Bassler, 1929. A. Left, colony in Döderlein Collection (MZS 2-1); right, colony collected by NSMT (NSMT-TeS22). B. Colony on hydroid stalk, from Sagami Bay (NSMT-TeS20). C. Distal end of branch showing young autozooids with multiporous, denticulate spiramen (NSMT-Te761). D. Young autozooids with umbonate processes on frontal shield (NSMTTe764). E. Mature autozooids with small suboral and other frontal avicularia (NSMT-Te761). F. Old autozooids, showing deeply immersed spiramen and orifices (NSMT-Te762). A-B = optical photographs; $\mathrm{C}-\mathrm{F}=$ SEM images. Scale bars: $\mathrm{A}=3 \mathrm{~mm} ; \mathrm{B}=2 \mathrm{~mm} ; \mathrm{C}-\mathrm{D}, \mathrm{F}=200 \mu \mathrm{m} ; \mathrm{E}=250 \mu \mathrm{m}$. 


\section{Description}

Colony yellow or white, small, fragile, dichotomously branching, almost two-dimensional (Fig. 11AB); up to $3 \mathrm{~cm}$ high. Branches flat, slender, 1.3-2.6 mm wide (average $1.9 \mathrm{~mm} ; \mathrm{n}=16$ ). Autozooids on both sides of branches; oval or hexagonal, zooidal boundaries distinct, zooids delineated by groove and suture line (Fig. 11E). Frontal shield minutely granulate, with marginal pores; sometimes bearing 2 or 3 low, umbonate processes along lateral or proximal margin (Fig. 11D), 40-80 $\mu \mathrm{m}$ in diameter (average $60 \mu \mathrm{m}, \mathrm{n}=14$ ). Spiramen large, circular, divided into 4-6 small denticulate pores (Fig. 11D). Peristome present, broadly oval in outline, not tubular (Fig. 11C); orifice indistinct in frontal view, proximal margin highly convex (Fig. 11C). One or two small suboral avicularia between orifice and spiramen (Fig. 11E); if single, positioned near midline and pointing distally or angled slightly distomedially or distolaterally; if paired, pointing distomedially; mandible short-triangular; crossbar incomplete. One to three frontal avicularia similar in size and shape to suboral avicularia situated around proximal and proximolateral margins of zooid (Fig. 11D). Basal part of colony consists of autozooids and kenozooids; 309-521 $\mu \mathrm{m}$ long (average $415 \mu \mathrm{m})$ by $202-383 \mu \mathrm{m}$ wide (average $244 \mu \mathrm{m})(\mathrm{n}=14)$. Basal autozooids heavily secondarily calcified; peristome and spiramen depression confluent, forming single oblong depression that also contains the suboral avicularia (Fig. 11F), common opening 112-203 $\mu \mathrm{m}$ long (average $146 \mu \mathrm{m}$ ) by $66-108 \mu \mathrm{m}$ wide (average $89 \mu \mathrm{m})(\mathrm{n}=10)$. Gonozooids lacking. Marginal vicarious avicularia not observed.

\section{Remarks}

Ortmann (1890) reported this species as Adeonella tuberculata (Busk, 1884) from Sagami Bay based on Döderlein's specimens, as it has two small avicularia between the orifice and spiramen. Adeonellopsis pentapora is quite small and fragile compared to the other adeonid species collected from Sagami Bay; it also occupies unstable substrates such as hydroid stems (Fig. 11B) and gastropod shells (Fig. 11A). Sakakura (1935) also reported a colony encrusting a gastropod shell from Toyama Bay. A colony of A. pentapora in the Döderlein collection is encrusted on a small shell of a dead gastropod inhabited by a hermit crab, and a colony collected from Sagami Bay in 2002 is encrusted on a different species of small shell of a dead gastropod. Canu \& Bassler (1929) reported Adeonellopsis pentapora from a broad area of the Indo-Pacific, including Japan (Tsugaru Strait). Harmer (1957) considered Adeonellopsis pentapora and A. tuberculata to be junior synonyms of Adeonellopsis yarraensis (Waters, 1881) based on having two small suboral avicularia and narrow branches. A. yarraensis, however, is currently regarded as a strictly fossil species and $A$. tuberculata as a Recent species in Australia; therefore, I consider $A$. pentapora to be a valid species.

\section{Distribution}

Philippines and Japan: detected in this study from Sagami Bay, Sagami Sea, Korea Strait, Wakasa Bay, Toyama Bay, Otsuchi, Ariake Sea, near Tanega-shima and Yaku-shima, and Ogasawara, at depths of 29-274 m. Adeonellopsis pentapora was not as abundant as other adeonid species in any collections or at any localities. Kataoka (1961) reported a fossil specimen from the Pleistocene Ryukyu Limestone of Kikai-jima, Kagoshima.

Adeonellopsis sparassis (Ortmann, 1890)

Figs 12-13

Adeonella sparassis Ortmann, 1890: 54, pl. 4, fig. 10.

Adeonella hexangularis Okada, 1920: 630, text fig. 7, pl. 8, fig. 10.

Adeonella hexangularis - Okada 1934: 17, pl. 2, fig. 2. - Mawatari 1952: 285.

Adeonellopsis sparassis - Hirose 2010: 52, pl. 88, figs A-G.

Reptadeonella sp. - Hirose 2010: 53, pl. 90, figs A-D. 


\section{Material examined}

Lectotype [designated herein]

JAPAN: colony, Sagami Bay, 1882, collected by L. Döderlein, MZS 1-2 (SEM specimen NSMT-Te745).

Paralectotypes [designated herein]

JAPAN: colony, Yokohama, 1891, collected by Rolle, MZS 1-1 (SEM specimen NSMT-Te747); colony, Sagami Bay, 1882, collected by L. Döderlein, MZS 1-3 (SEM specimen NSMT-Te740).
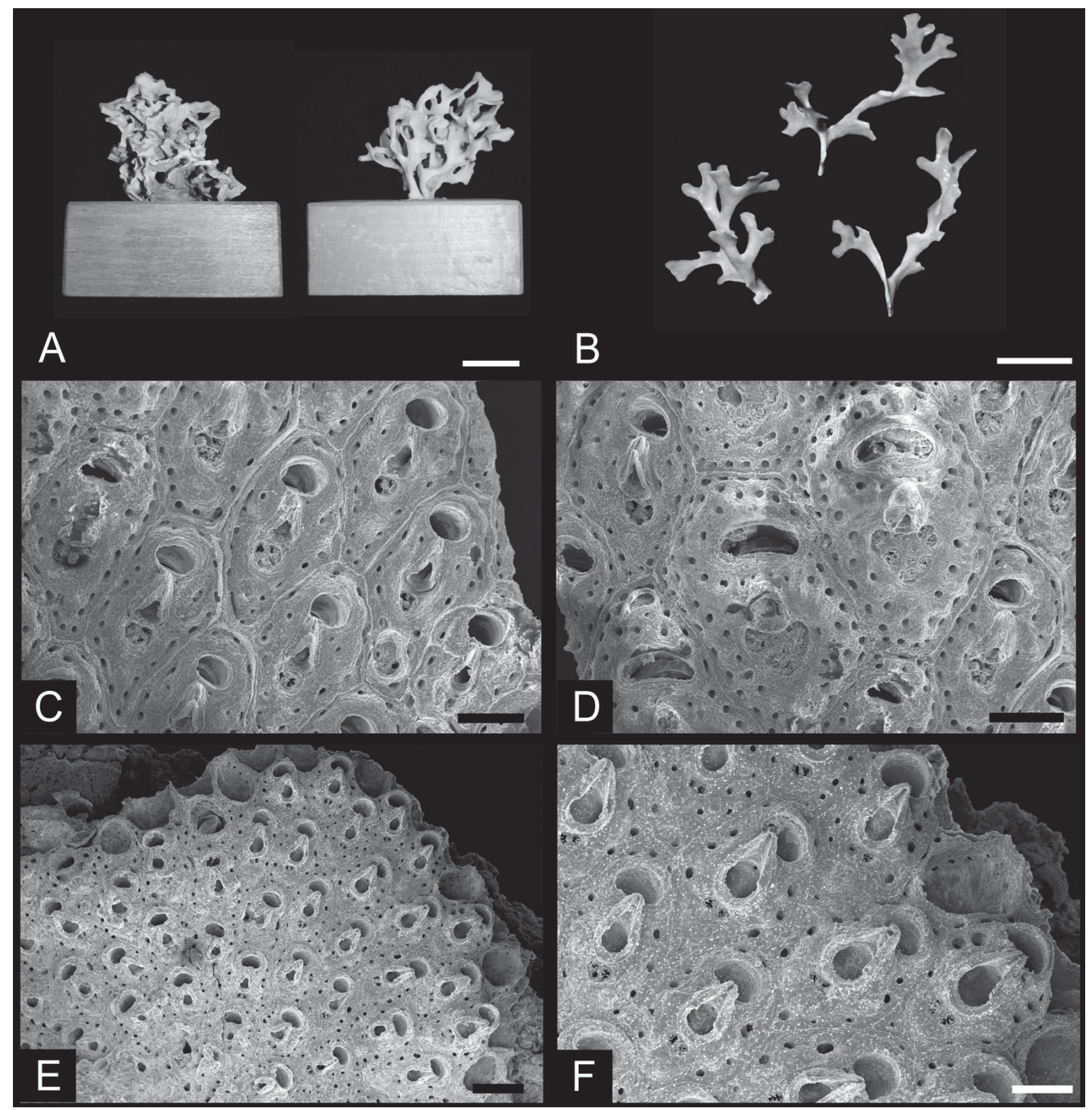

Fig. 12. Adeonellopsis sparassis (Ortmann, 1890). A. Left, lectotype (MZS 1-2); right, paralectotype (MZS 1-1) from among Ortmann's (1890) syntypes in the Döderlein Collection. B. Colonies collected at Tanegashima (NSMT-Te774). C. Autozooids (MZS 1-2) (NSMT-Te745). D. Gonozooids (MZS 1-2) (NSMT-Te745). E. Young, encrusting colony in Showa Emperor Collection (NSMT-BryR362). F. Enlargement showing young autozooids with small spiramen (NSMT-BryR362). A-B = optical photographs; $\mathrm{C}-\mathrm{F}=\mathrm{SEM}$ images. Scale bars: $\mathrm{A}-\mathrm{B}=2 \mathrm{~cm} ; \mathrm{C}=150 \mu \mathrm{m}$; D-E $=200 \mu \mathrm{m} ; \mathrm{F}=100 \mu \mathrm{m}$. 


\section{Other material examined}

JAPAN: colonies collected from Suzaki, Izu, Sagami Sea, in the Emperor Showa collection at NSMT (NSMT-BryR362); colonies collected from Ariake Sea (NSMT-Te770), from near Yakushima and Tanegashima (NSMT-Te772, Te773, Te774); from off Shimoda (NSMT-Te890); from south of Nagannu Island (NSMT-Te750, Te803); from Ogasawara (NSMT-Te771).

\section{Measurements}

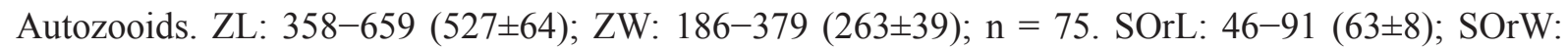
72-118 (89 \pm 9$) ; \mathrm{n}=53$. SAvL: 106-174 (139 \pm 15$) ; \mathrm{SAvW}: 48-105$ (75 \pm 13$) ; \mathrm{n}=75$. SpL: 29-76 (54 \pm 11$)$; SpW: $32-83(52 \pm 11) ; \mathrm{n}=74$.

Gonozooids. ZL: 623-855 (722 \pm 54$)$; ZW: 445-630 (534 \pm 54$) ; \mathrm{n}=24$. SOrL: $52-112$ (77 \pm 14$)$; SOrW: 136-265 (223 \pm 26$) ; \mathrm{n}=21$. SAvL: 137-218 (162 \pm 22$)$; SAvW: 88-117 (104 \pm 8$) ; \mathrm{n}=21$. SpL: $97-185$ (129 \pm 20$) ;$ SpW: 99-267 (159 \pm 33$) ; \mathrm{n}=23$.

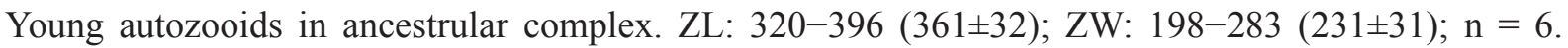

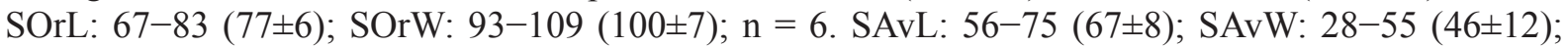
$\mathrm{n}=6$. SpL: $18-31(23 \pm 5) ;$ SpW: $31-56(41 \pm 9) ; \mathrm{n}=6$.

Vicarious avicularia at branch margins. L: 253-476 (327 \pm 69$) ; \mathrm{W}: 154-228(174 \pm 26) ; \mathrm{n}=8$.

\section{Description}

Colony brownish yellow, dichotomously branching, irregularly spreading, many proximal branches anastomosing, forming compact three-dimensional structure (Fig. 12A); anastomosed basal region can exceed $4 \mathrm{~cm}$ high (3.67-4.64 cm). Branches flat, ribbon-like, variable in width (Fig. 12B); 1.6-8.6 mm wide (average $4.0 \mathrm{~mm} ; \mathrm{n}=101$ ); much wider basally. Autozooids on both sides of branch, oval or hexagonal, outlined by deep marginal groove (Figs 12C, 13B); younger zooids at end of branch shorter (average $382 \mu \mathrm{m} ; \mathrm{n}=6$ ) and broader (average $324 \mu \mathrm{m} ; \mathrm{n}=9$ ) than older zooids in anastomosed basal region. Frontal shield minutely granulate, with numerous marginal pores and small ascopore (Figs 12C, 13B). Spiramen almost circular in younger zooids, divided into 3-5 denticulate pores (Fig. 13B, E); slightly broader in older zooids in basal part of colony (average $66 \mu \mathrm{m} ; \mathrm{n}=12$ ). Peristome transversely oval, roughly semicircular in outline, not tubular; primary orifice submersed in peristome. Triangular suboral avicularium in center of frontal shield, between spiramen and orifice, directed distally (Figs 12F, 13B). Rarely autozooids have an additional, smaller frontal avicularium, budded from frontal areolae near proximal margin of zooid, directed distally (Fig. 12C). Gonozooids (Figs 12D, 13C, F) occur at branch bifurcations (Fig. 13C, F); larger than autozooids, hexagonal; with single or double rows of marginal pores (Fig. 12D); slightly crescentic orifice compressed, much wider than long; spiramen large, rounded-triangular or oval in outline, divided into 6-10 small, denticulate pores (Figs 12D, 13C). Gonozooids in basal part of colony much broader (average $602 \mu \mathrm{m} ; \mathrm{n}=6$ ), and with a slightly larger spiramen (average $142 \mu \mathrm{m}$ long by $199 \mu \mathrm{m}$ wide; $\mathrm{n}=5$ ). Vicarious avicularia (Fig. 13A) often along edges of branches; triangular, directed distally; about same length as autozooids; rostrum length about half of autozooid length. One young colony observed (Fig. 13D); encrusting, circular, $1.2 \mathrm{~cm}$ in diameter; ancestrular complex consisting of six zooids radiating from center. Autozooids in young, encrusting colonies (Figs 12E-F, 13D) oval, surrounded by distinct shallow groove; frontal shield with few marginal pores and 4-6 knobs (Fig. 12F); secondary orifice broadly semicircular; spiramen circular, divided into 2-4 small, denticulate pores; triangular suboral avicularium much smaller than that of mature autozooids; between spiramen and orifice, directed distally, often partly overlapping proximal orificial margin (Fig. 12F). 


\section{Remarks}

Ortmann's specimens comprise only the basal, anastomosed parts of colonies (Fig. 8A), and zooidal characters in these specimens are identical to those in the basal parts of the more-complete Adeonellopsis sparassis colonies that I studied. Adeonellopsis sparassis resembles A. sulcata (Milne Edwards, 1836) in having a multiporous spiramen and small, distally directed suboral avicularia, but differs from the latter in having a smaller, circular spiramen. MacGillivray's (1880: plate 48, fig. 7) illustration of Eschara mucronata (MacGillivray, 1868) (= A. sulcata) appears to represent the basal part of a

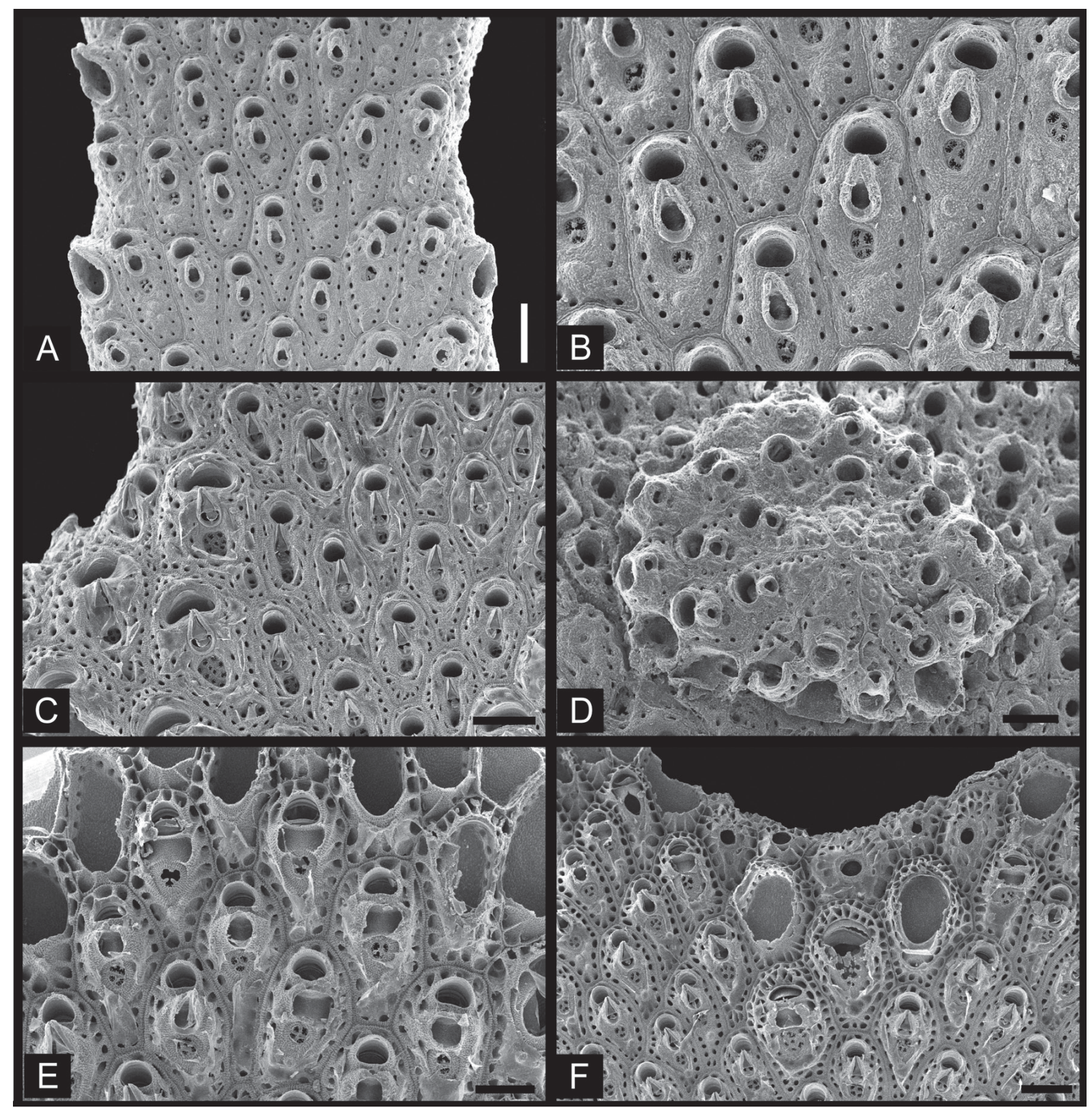

Fig. 13. Adeonellopsis sparassis (Ortmann, 1890). A. Autozooids and marginal vicarious avicularia (NSMT-Te772). B. Enlargement of autozooids (NSMT-Te772). C. Autozooids and gonozooids (NSMTTe774). D. Young, encrusting colony (NSMT-Te770). E. Young autozooids, showing circular spiramen and large areolar pores (NSMT-Te774). F. Young autozooids and gonozooids at branch bifurcation (NSMT-Te774). SEM images. Scale bars: A, C $=300 \mu \mathrm{m} ; \mathrm{B}=150 \mu \mathrm{m} ; \mathrm{D}-\mathrm{E}=200 \mu \mathrm{m} ; \mathrm{F}=300 \mu \mathrm{m}$. 
colony of Adeonellopsis that resembles A. sparassis. However, as I did not examine MacGillivray's type specimen, I do not include it in the synonymy of $A$. sparassis.

I identified an encrusting colony in the Emperor Showa collection as a young colony of A. sparassis based on the small, round multiporous spiramen and the triangular suboral avicularium between the ascopore and orifice. Hayward \& McKinney (2002) described a similar ancestrular complex consisting of six zooids in the closely related encrusting genus Reptadeonella. Bock \& Cook (2000) also reported a similar encrusting ancestrular complex in Adeonellopsis, but they described a remarkably different bipolar ancestrular colony in the articulated genus Adeona. I conclude the ancestrular complex in the Emperor Showa collection to be A. sparassis rather than Reptadeonella or the other genera, based on the orifice shape and the multiporous spiramen. The knobs on the frontal shield of zooids in the encrusting colony appear to be a character common to young zooids in several adeonid species.

Okada (1920) described another adeonid bryozoan, Adeonella hexangularis Okada, 1920, from Misaki (Sagami Bay) and the Kagoshima Gulf (southern Kyushu), which surely is Adeonellopsis according to his description of a multiporous spiramen. Due to the limited original description and apparent loss of the type specimens, the identity of $A$. hexangularis is unclear, but Okada's description of an anastomosed colony morphology, frontal shields with a single or double rows of marginal pores, and gonozooids located at branch bifurcation and having a broad, proximodistally compressed orifice indicate that it is conspecific with $A$. sparassis and constitutes a junior synonym of the latter. Mawatari (1952) reported nominal A. hexangularis from off Wakayama and Minabe, Kii Peninsula, without a description; according to this record, A. sparassis is probably also distributed around the Kii Peninsula.

\section{Distribution}

Japan: detected in this study from Sagami Bay, Tokyo Bay (Yokohama), Sagami Sea (Izu Peninsula), Ariake Sea, Nansei Islands (near Yakushima and west of Okinawa), and Ogasawara, at depths of 24$141 \mathrm{~m}$. It was collected from eastern Sagami Bay and western Sagami Sea by Döderlein and Emperor Showa, but was not found recently in those areas by NSMT.

\section{Adeonellopsis parvirostrum sp. nov. urn:Isid:zoobank.org:act:E46E9CD1-84F7-41DC-9AE9-9164B5262E5E}

Figs 10B, 14-15

Adeona n. sp. - Hirose 2010: 50, pl. 86, figs A-D.

\section{Diagnosis}

Colony dichotomously branching; branches flat, roughly 3-4 mm wide. Autozooids oval, distinct, delineated by a deep groove; with a single row of marginal pores. Frontal shield smooth or slightly granulated. Peristome deep, oval. Spiramen monoporous. Two to six tiny pores in frontal wall proximal to orifice. Suboral avicularia triangular, small, almost same size as spiramen; in center of frontal shield, distal to spiramen, directed distally. Triangular marginal vicarious avicularia present. Gonozooids slightly broader than autozooids; orifice broad, proximodistally compressed, with slightly convex proximal margin; spiramen and avicularia almost same size as in autozooids.

\section{Etymology}

The specific name derives from the Latin parvus (small) and rostrum (used as a noun in apposition), referring to the small rostrum of the suboral avicularia. 


\section{Material examined}

\section{Holotype}

JAPAN: two branches of single colony collected by NSMT, north-northwest of Hachijo-jima Island, $33^{\circ} 20^{\prime} 54.48^{\prime \prime} \mathrm{N}, 139^{\circ} 41^{\prime} 11.16^{\prime \prime} \mathrm{E}$ to $33^{\circ} 21^{\prime} 4.32^{\prime \prime} \mathrm{N}, 139^{\circ} 40^{\prime} 30.84^{\prime \prime} \mathrm{E}, 185-213 \mathrm{~m}$ depth, with CB dredge from R/V Tansei-maru, 26 Nov. 2007 (NSMT-TeS25).

\section{Paratypes}

JAPAN: branch of colony collected by NSMT, same collection data as for holotype (NSMT-TeS27); four dried colony fragments collected by NSMT, NE off Hachijo-jima Island, 333 $34^{\prime} 6.00^{\prime \prime} \mathrm{N}, 140^{\circ} 15^{\prime} 54.00^{\prime \prime} \mathrm{E}$ to $33^{\circ} 34^{\prime} 24.00^{\prime \prime} \mathrm{N}, 140^{\circ} 16^{\prime} 0.00^{\prime \prime} \mathrm{E}, 179-182 \mathrm{~m}$ depth, from R/V Shinyo-maru, 23 Oct. 2003 (NSMTTeS26); small branches of colony collected by NSMT, N of Hachijo-jima Island, 33 $26^{\circ} 48.00^{\prime \prime} \mathrm{N}$, $139^{\circ} 42^{\prime} 42.00^{\prime \prime}$ E to $33^{\circ} 27^{\prime} 0.00^{\prime \prime} \mathrm{N}, 139^{\circ} 42^{\prime} 24.00^{\prime \prime}$ E, 200-211 m depth, from R/V Shinyo-maru, 21 Oct. 2003 (NSMT-TeS28); several branches of colony collected by NSMT, southwest of Boso Peninsula, $\sim^{3} 4^{\circ} 51^{\prime} \mathrm{N}, 139^{\circ} 40^{\prime} \mathrm{E}, 135-172 \mathrm{~m}$ depth, from R/V Shinyo-maru, 25 Oct. 2002 (NSMT-TeS29); several branches of colony, Oshima Shin-sone, 28 $8^{\circ} 52^{\prime} 24.60^{\prime \prime} \mathrm{N}, 129^{\circ} 33^{\prime} 5.40^{\prime \prime}$ E to $28^{\circ} 53^{\prime} 1.20^{\prime \prime} \mathrm{N}, 129^{\circ} 33^{\prime} 5.40^{\prime \prime} \mathrm{E}$, 169-172 m depth, with biological dredge from T/V Toyoshio-maru, collected 24 May 2011 (NSMTTe780); several branches of colony, Oshima Shin-sone, $28^{\circ} 52.511^{\prime} \mathrm{N}, 129^{\circ} 33.233^{\prime} \mathrm{E}$ to $28^{\circ} 52.631^{\prime} \mathrm{N}$,



Fig. 14. Adeonellopsis parvirostrum sp. nov. A. Colony branches from Oshima Shin-sone, $\mathrm{N}$ of Amami Oshima (NSMT-Te780). B. Distal end of branch (NSMT-TeS26). C. Young autozooids and some gonozooids (four of them are indicated with asterisks) at distal end of branch (NSMT-TeS26). D. Gonozooids with broad, curved orifice, small triangular avicularia, and small spiramen (NSMTTeS26). A-B = photomicrographs; $\mathrm{C}-\mathrm{D}=$ SEM images. Scale bars: $\mathrm{A}=1 \mathrm{~cm}$; $\mathrm{B}-\mathrm{D}=500 \mu \mathrm{m}$. 
129 33.313' E, 165-200 m depth, with biological dredge from T/V Toyoshio-maru, collected 29 May 2012 (NSMT-Te807).

\section{Measurements}

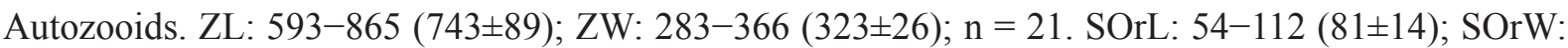
84-114 (102 \pm 8$) ; \mathrm{n}=25$. SAvL: 40-82 (58 \pm 10$)$; SAvW: 21-46 (34 \pm 6$) ; \mathrm{n}=51 . \mathrm{SpL}: 23-45(33 \pm 6)$; SpW: $23-40(33 \pm 4) ; \mathrm{n}=38$.

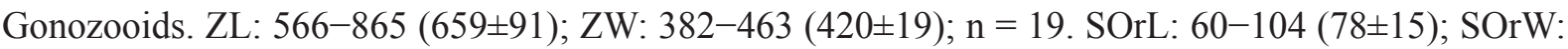
$118-132(123 \pm 5) ; \mathrm{n}=11$.

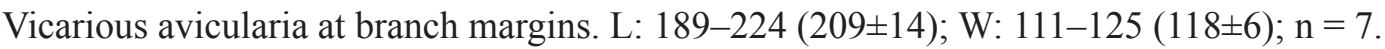

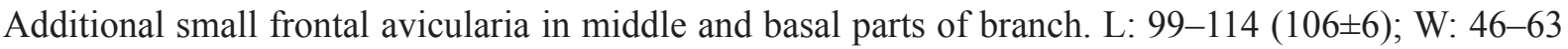
$(55 \pm 5) ; \mathrm{n}=10$.

\section{Description}

Colony yellowish white, dichotomously branching. Branches flat, slender, 2.607-4.433 mm wide (average $3.3 \mathrm{~mm} ; \mathrm{n}=10$ ); (Fig. 14A). Autozooids on both sides of branches. Autozooids oval, distinct, delineated by deep groove (Fig. 14B-C). Frontal shield umbonuloid (Fig. 10B). Frontal shield smooth or

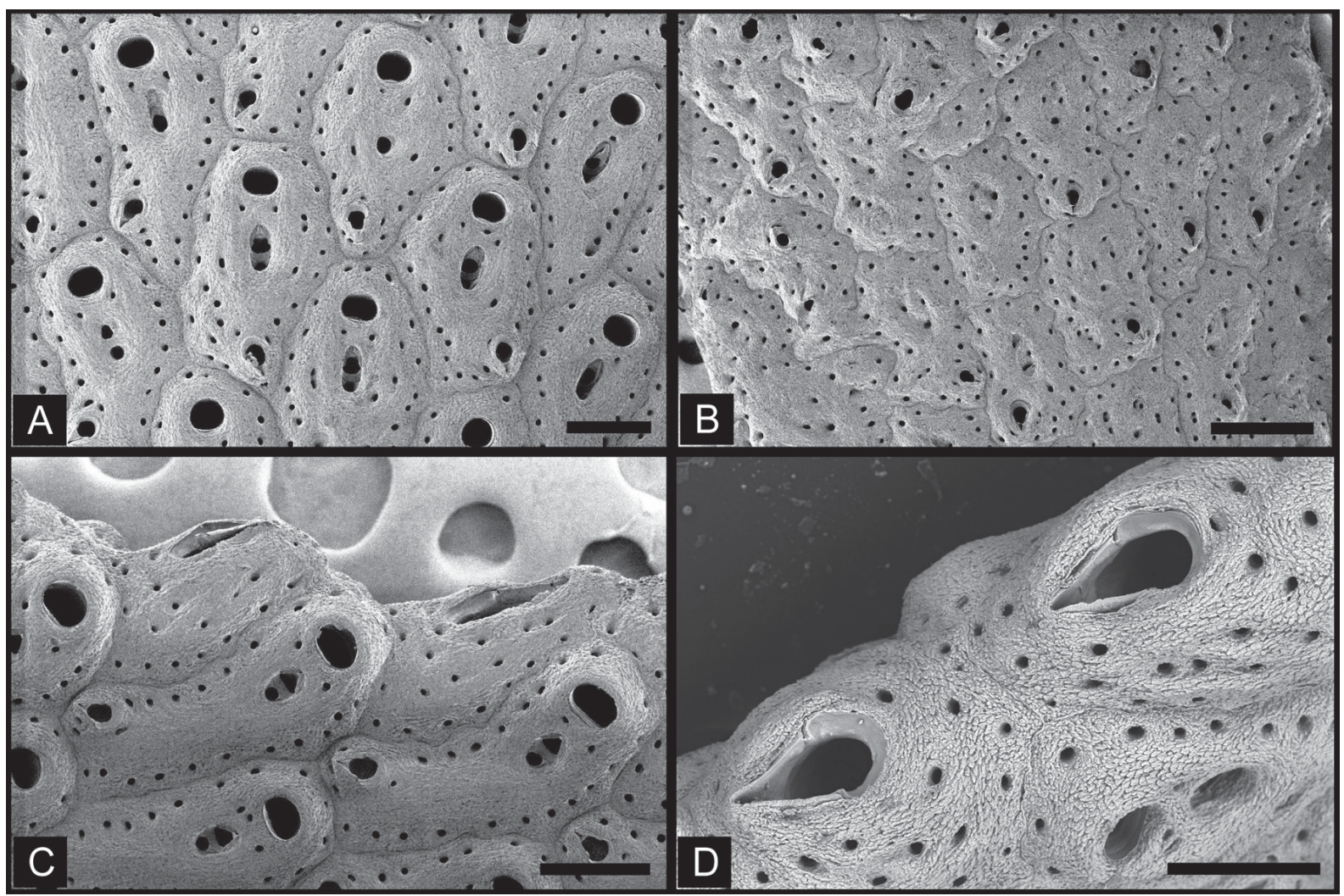

Fig. 15. Adeonellopsis parvirostrum sp. nov. A. Middle of branch, showing autozooids lacking suboral avicularium (NSMT-Te780). B. Kenozooids in old part of branch (NSMT-Te780). C. Autozooids and marginal vicarious avicularia at periphery of branch (NSMT-Te780). D. Lateral view of vicarious avicularium at branch bifurcation (NSMT-Te780). SEM images. Scale bars: A, C-D = $200 \mu \mathrm{m}$; B = $300 \mu \mathrm{m}$. 
with minute granules or wrinkles; with single row of marginal pores. Peristome deep, secondary orifice transversely oval. Spiramen in center of frontal shield; monoporous, circular (Figs 14D, 15A), rarely divided into two or three non-denticulate pores. Two to six tiny, irregular frontal pores proximal to orifice; roughly same size as marginal pores (Figs 14C-D, 15A). Small suboral avicularium (Figs 14D, 15A, C) just distal to and often abutting spiramen; rostrum short, with triangular mandible; separated from orifice by distance up to several times greater than mandible length; directed distally. Additional small frontal avicularia lacking in younger part of branch (Fig. 14C). Vicarious avicularia present (Fig. 15C-D); marginal, almost three times length of suboral avicularia; with triangular mandible. In middle and basal parts of colony, autozooids somewhat irregular in shape; borders indistinct; 572-774 $\mu \mathrm{m}$ long (average $665 \mu \mathrm{m})$ by $238-328 \mu \mathrm{m}$ wide (average $274 \mu \mathrm{m})(\mathrm{n}=12)$; frontal shields heavily secondarily calcified; orifice nearly circular, 76-93 $\mu \mathrm{m}$ long (average $85 \mu \mathrm{m})$ by $73-115 \mu \mathrm{m}$ wide (average $90 \mu \mathrm{m})(\mathrm{n}=8)$. In basal autozooids, spiramen consists of small single pore, 26-33 $\mu \mathrm{m}$ (average $30 \mu \mathrm{m}$ ) long by 23-31 $\mu \mathrm{m}$ wide (average $27 \mu \mathrm{m})(\mathrm{n}=4)$; suboral avicularia slightly larger than in non-basal zooids, 107-122 $\mu \mathrm{m}$ long (average $112 \mu \mathrm{m})$ by $41-47 \mu \mathrm{m}$ wide (average $44 \mu \mathrm{m})(\mathrm{n}=5$ ); spiramen and suboral avicularia submerged in common depression in heavily calcified frontal shield. Autozooids in middle and basal parts of branch bear additional small frontal avicularium, often on proximal margin of zooid (Fig. 15A, C); directed proximally or proximolaterally. Basal part of colony consists of irregularly shaped kenozooids that bear several small frontal avicularia (Fig. 15B). Gonozooids (Fig. 14C-D) slightly broader than autozooids; orifice crescentic, much wider than long, with convex proximal margin; spiramina and suboral avicularia roughly same size as in autozooids.

\section{Remarks}

Adeonellopsis parvirostrum sp. nov. fits the original description of Adeonellopsis japonica in having a small, circular spiramen and small suboral avicularium, but its avicularium is much smaller than in the latter. Young autozooids of A. parvirostrum sp. nov. lack the striation perpendicular to the margin seen on the rim of young zooids of A. japonica. Adeonellopsis parvirostrum sp. nov. resembles A. lichenoides in the basal part of the colony (compare Fig. 5D with Fig. 15B), but differs from the latter in the presence of a distally directed suboral avicularium between the orifice and spiramen in older parts of branches. Some small frontal avicularia are sparsely surrounded by the remains of associated areolae of original autozooids and/or kenozooids (Fig. 15A-C). Some of the specimens of A. parvirostrum sp. nov. I observed were pinkish, although this may have resulted from artificial staining of another organism, as other bryozoan colonies in the same bottle were also pinkish.

\section{Distribution}

Japanese Pacific waters: north of Hachijo-jima Island, Sagami Sea, and near Amami Oshima, at depths of $135-213 \mathrm{~m}$.

Adeonellopsis toyoshioae sp. nov.

urn:1sid:zoobank.org:act:B7DA81C8-D492-4AEA-A953-CB19EDF8EF45

Fig. 16

Adeonellopsis subteres - Hayami 1971: 87, pl. 11, fig. 4.

\section{Diagnosis}

Colony dichotomously branching; branches flat, or nearly cylindrical, slender, roughly $0.7-1.4 \mathrm{~mm}$ wide. Autozooids oval, distinct, delineated by deep groove; with single row of small marginal pores. Frontal shield entirely with granules and wrinkles, forming thickened ridge around spiramen. Peristome raised, transversely broad. Spiramen large, equal to or greater than secondary orifice in size, variable in 
shape, divided into 4-8 stellate pores. Suboral avicularia triangular, large, distal to spiramen; directed distally or distolaterally, rostrum tip extending over proximal margin of orifice. Gonozooids unknown.

\section{Etymology}

The specific name refers to the T/V Toyoshio-maru of Hiroshima University.



Fig. 16. Adeonellopsis toyoshioae sp. nov. A. Colonies from Amami Oshima (NSMT-Te776). B. Branch showing autozooids with broad multiporous spiramen (NSMT-Te776). C. Branch showing crenulate periphery, with tubular peristomes and acute avicularia (NSMT-Te776). D. Branch bifurcation lacking vicarious avicularia (NSMT-Te776). E. Distal end of branch showing young autozooids with large multiporous spiramen (NSMT-Te776). F. Old autozooids with immersed spiramen (NSMT-Te776). A = optical photograph; B-F $=$ SEM images. Scale bars: A $=5 \mathrm{~mm} ; \mathrm{B}, \mathrm{E}=300 \mu \mathrm{m} ; \mathrm{C}, \mathrm{F}=500 \mu \mathrm{m}$; D = $200 \mu \mathrm{m}$. 


\section{Material examined}

\section{Holotype}

JAPAN: small colony collected at Takatori, southwest of Otsuki, Kochi Prefecture, $\sim 32^{\circ} 30^{\prime} \mathrm{N}, 132^{\circ} 50^{\prime} \mathrm{E}$, by coral fishing net, 118-120 m depth, F/V Yuryo-maru, 29 Sep. 2010 (NSMT-Te777).

\section{Paratypes}

JAPAN: small colony, same collection data as for holotype (NSMT-Te779); small branches of colony, north of Amami Oshima, 28 $8^{\circ} 2^{\prime} 38.40^{\prime \prime} \mathrm{N}, 129^{\circ} 33^{\prime} 13.80^{\prime \prime} \mathrm{E}, 178 \mathrm{~m}$ depth, by biological dredge, T/V Toyoshio-maru, 24 May 2009 (NSMT-Te776); several branches of colony, collected at Oshima Shin-sone, $28^{\circ} 52^{\prime} 24.60^{\prime \prime} \mathrm{N}, 129^{\circ} 33^{\prime} 5.40^{\prime \prime}$ E to $28^{\circ} 53^{\prime} 1.20^{\prime \prime} \mathrm{N}, 129^{\circ} 33^{\prime} 5.40^{\prime \prime}$ E, $169-172 \mathrm{~m}$ depth, by biological dredge, T/V Toyoshio-maru, 24 May 2011 (NSMT-Te778); colony collected by NSMT, north of Hachijo-jima Island, $33^{\circ} 26^{\prime} 48.00^{\prime \prime} \mathrm{N}, 139^{\circ} 42^{\prime} 42.00^{\prime \prime}$ E to $33^{\circ} 27^{\prime} 0.00^{\prime \prime} \mathrm{N}, 139^{\circ} 42^{\prime} 24.00^{\prime \prime}$ E, 170 176 m depth, RV Shinyo-maru, 21 Oct. 2003 (NSMT-TeS23); colony collected by NSMT, north of Hachijo-jima Island, $33^{\circ} 25^{\prime} 60.00^{\prime \prime} \mathrm{N}, 139^{\circ} 41^{\prime} 54.00^{\prime \prime} \mathrm{E}$ to $33^{\circ} 26^{\prime} 6.00^{\prime \prime} \mathrm{N}, 139^{\circ} 41^{\prime} 36.00^{\prime \prime} \mathrm{E}, 160-190 \mathrm{~m}$ depth, RV Shinyo-maru, 21 Oct. 2003 (NSMT-TeS24); several branches of colony, Oshima Shin-sone, $28^{\circ} 52.511^{\prime} \mathrm{N}, 129^{\circ} 33.233^{\prime} \mathrm{E}$ to $28^{\circ} 52.631^{\prime} \mathrm{N}, 129^{\circ} 33.313^{\prime} \mathrm{E}, 165-200 \mathrm{~m}$ depth, by biological dredge, T/V Toyoshio-maru, 29 May 2012 (NSMT-Te808); several branches of colony, north of Tanegashima Island, $30^{\circ} 53.317^{\prime} \mathrm{N}, 131^{\circ} 02.565^{\prime} \mathrm{E}$ to $30^{\circ} 53.336^{\prime} \mathrm{N}, 131^{\circ} 02.747^{\prime} \mathrm{E}, 165-200 \mathrm{~m}$ depth, by biological dredge, T/V Toyoshio-maru, 30 May 2012 (NSMT-Te802).

\section{Measurements}

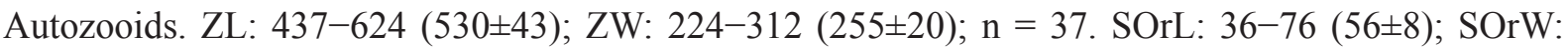
63-102 (75 \pm 10$) ; \mathrm{n}=28$. SAvL: 91-174 (136 \pm 19$) ;$ SAvW: 52-97 (72 \pm 9$) ; \mathrm{n}=56 . \mathrm{SpL}: 62-262(114 \pm 46)$; SpW: $35-116(72 \pm 16) ; \mathrm{n}=61$.

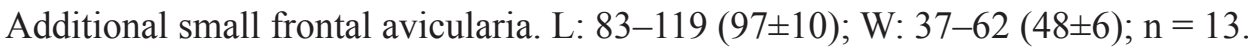

\section{Description}

Colony yellowish white, dichotomously branching, small, up to $3 \mathrm{~cm}$ high. Branches flat or nearly cylindrical, slender (Fig. 16A); 0.7-1.4 mm wide (average $1.0 \mathrm{~mm}, \mathrm{n}=15$ ). Autozooids all around branches; oval, distinct, delineated by deep groove, with single row of small marginal pores (Fig. 16B). Frontal shield raised from margin, entirely textured with small granules and wrinkles, forming a thickened ridge around spiramen; ridge often bears up to four low, smooth umbos 40-78 $\mu \mathrm{m}$ in diameter (average $60 \mu \mathrm{m}, \mathrm{n}=52$ ) (Fig. 16D). Peristome raised, thick-walled distally and laterally, transversely broad; secondary orifice semicircular to transversely oval (Fig. 16B, D). Primary orifice hidden in peristome in frontal view. Spiramen large, size roughly equal to or greater than area of secondary orifice; variable in shape, divided into 4-8 stellate pores (Fig. 16D-E). Single large, triangular suboral avicularium between orifice and spiramen, directed distally or distolaterally (Fig. 16B, E); rostrum acute, tip often extending over proximal margin of orifice (Fig. 16D); mandible elongate-triangular; opesial opening oval; crossbar lacking. Some zooids have additional, smaller frontal avicularium budded, near proximal margin of zooid, pointing in any direction. Marginal vicarious avicularia triangular, directed distally; $312 \mu \mathrm{m}$ long by $134 \mu \mathrm{m}$ wide $(\mathrm{n}=1)$. Gonozooids unknown.

\section{Remarks}

Adeonellopsis toyoshioae sp. nov. resembles A. subteres (Römer, 1863) in the number of alternate zooidal rows, raised margin of the frontal shield, and a large ascopore occupying a broad area of the frontal shield (Römer, 1863: pl. XXXV, fig. 6). However, A. subteres was originally reported as a fossil from Germany and occurs in the Eocene (Canu 1907; Braga 1963) and Oligocene (David \& Pouyet 1968) deposits of Europe. I therefore concluded that $A$. toyoshioae sp. nov. represents a new species. Moreover, the Recent 
Adeonellopsis distoma (Busk, 1858) from the eastern N Atlantic is closely related to both species; Adeonellopsis distoma resembles A. toyoshioae sp. nov. in having a subtubular peristome and a large area of multiporous spiramen consisting of about seven pores. Adeonellopsis distoma, however, differs from $A$. toyoshioae sp. nov. in having an elongated spiraminal area, with usually two rows of pores, in having larger suboral avicularia and fewer zooidal rows comprising the branches, and in lacking the marginal umbos. Adeonellopsis toyoshioae sp. nov. also resembles $A$. sparassis in having a multiporous ascopore with more than four denticulate pores, and a single suboral avicularium extending over the proximal margin of the orifice. However, the ascopore in A. toyoshioae sp. nov. is not circular as in A. sparassis and occupies a much larger area of the frontal shield. In addition, A. toyoshioae sp. nov. has branches less than $2.0 \mathrm{~mm}$ wide, whereas those in A. sparassis are usually wider than $2.5 \mathrm{~mm}$. Finally, the suboral avicularium is often directed slightly distolaterally in A. toyoshioae sp. nov., whereas it points directly distally $A$. sparassis.

The marginal umbos evident on younger zooids in A. toyoshioae sp. nov. are identical in size to those in A. pentapora; these umbos are also a characteristic feature of younger zooids in these species.

\section{Distribution}

Japanese Pacific waters: north of Hachijo-jima Island, southwest of Kochi Prefecture, and the northern Nansei Islands (near Amami Oshima and Tanegashima); at depths of 118-200 m. Hayami (1971) reported this species from fossiliferous sandstone in the Pliocene Shinzato Tuff (Shinzato Formation) on Okinawa Island, which is close to the Recent distribution in Japan.

\section{Taxonomic key to Japanese adeonid species}

1. Orifice circular; single peristomial spiramen proximal to orifice; no avicularia between orifice and spiramen; frontal shield with many small pores and several avicularia .....2...Adeonella Busk, 1884

- Orifice oval; spiramen single or multiporous; single or paired avicularia between orifice and spiramen; frontal shield normally bearing only marginal pores ..............Adeonellopsis MacGillivray, 1886

2. Branch width reaches more than $3 \mathrm{~mm}$; generally large vicarious avicularia present at branch bifurcations; generally more than two avicularia on frontal shield; areolar pores nearly uniform and circular; $\mathrm{L} / \mathrm{W}$ ratio of frontal avicularia generally less than 2.0

Adeonella cf.lichenoides (Lamarck, 1816)

- Branch width less than $2.5 \mathrm{~mm}$; often lacking a large vicarious avicularium at branch bifurcations; generally single frontal avicularium on frontal shield; areolar pores irregular in shape and often slitlike; L/W ratio of frontal avicularia generally greater than 2.0 ..........Adeonella jahanai sp. nov.

3. Autozooidal spiramen small, 1-2 openings; openings not denticulate .......................

- Autozooidal spiramen large, multiporous with more than four openings; openings denticulate ......6

4. Branches less than $2.0 \mathrm{~mm}$ wide; suboral avicularium abutting orifice, separate from spiramen, slightly curved, directed distolaterally Adeonellopsis arculifera (Canu \& Bassler, 1929)

- Branches greater than $3.0 \mathrm{~mm}$ wide; suboral avicularium abutting spiramen, rostrum straight, directed laterally or distolaterally .5

5. Suboral avicularium large, rostral width equal to or greater than orifice width; rostrum extending from spiramen to orificial margin .... Adeonellopsis japonica (Ortmann, 1890)

- Suboral avicularium small, rostrum narrower than orifice; avicularium distant from orifice Adeonellopsis parvirostrum sp. nov.

6. Suboral avicularia small, single or paired ........Adeonellopsis pentapora Canu \& Bassler, 1929

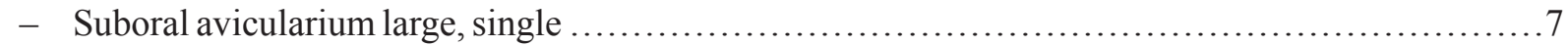


7. Branches usually greater than $2.5 \mathrm{~mm}$ wide; suboral avicularium directed distally; peristome not tubular; autozooidal spiramen width less than orifice width; spiramen circular in marginal autozooids Adeonellopsis sparassis (Ortmann, 1890)

- Branches usually less $2.0 \mathrm{~mm}$ wide; suboral avicularia directed distolaterally; peristome tubular; autozooidal spiramen width equal to or greater than orifice width; spiramen oval or irregular in marginal autozooids Adeonellopsis toyoshioae sp. nov.

\section{Discussion}

This study detected eight adeonid bryozoan species in Japanese waters, including a new record for Japan and three new species. It is the first review of Japanese adeonid bryozoans since Ortmann (1890) published the first monographic treatment of Japanese bryozoans. In a taxonomic key to Japanese cheilostome bryozoans published in Japanese, Okada (1918) established another adeonid bryozoan species, Adeonella vulgaris Okada, 1918, which I have not treated herein; the only description was that it has flat, antler-like branches with autozooids on both sides. Okada (1934) later provided a more detailed description based on material from Shimoda (western Sagami Sea); Adeonella vulgaris is surely not an adeonid because Okada (1934) mentions a globose ovicell perforated by a longitudinal slit. This species belongs in some other group that includes erect bryozoans, such as Cigclisula Canu \& Bassler, 1927 in the family Colatooeciidae Winston, 2005.

The six species of Adeonellopsis described herein show clear-cut differences in the size and shape of the spiramen and suboral avicularium (Fig. 17). The direction of the suboral avicularium and character of denticulation in the spiramen have been regarded as important diagnostic characters for species in this genus. Although they are often immersed in old zooids, the spiramen and suboral avicularia seem to be strongly constrained in size and shape from early ontogeny, and their morphology provides good diagnostic characters throughout development.

Further studies on adeonid taxonomy are needed. Adeonid larvae settle rapidly, after only a few hours in the water column, and are unlikely to disperse broadly. However, some adeonid species are supposedly broadly distributed, having been reported across several oceans: A. lichenoides, for example, is cited to occur from East Africa to the eastern Pacific and from southern Australia to Japan. It will be informative to examine these broadly distributed species using molecular data, to determine whether they actually represent species complexes that include species previously undetected through morphology, and to further clarify their taxonomy, ecology, and biogeography.
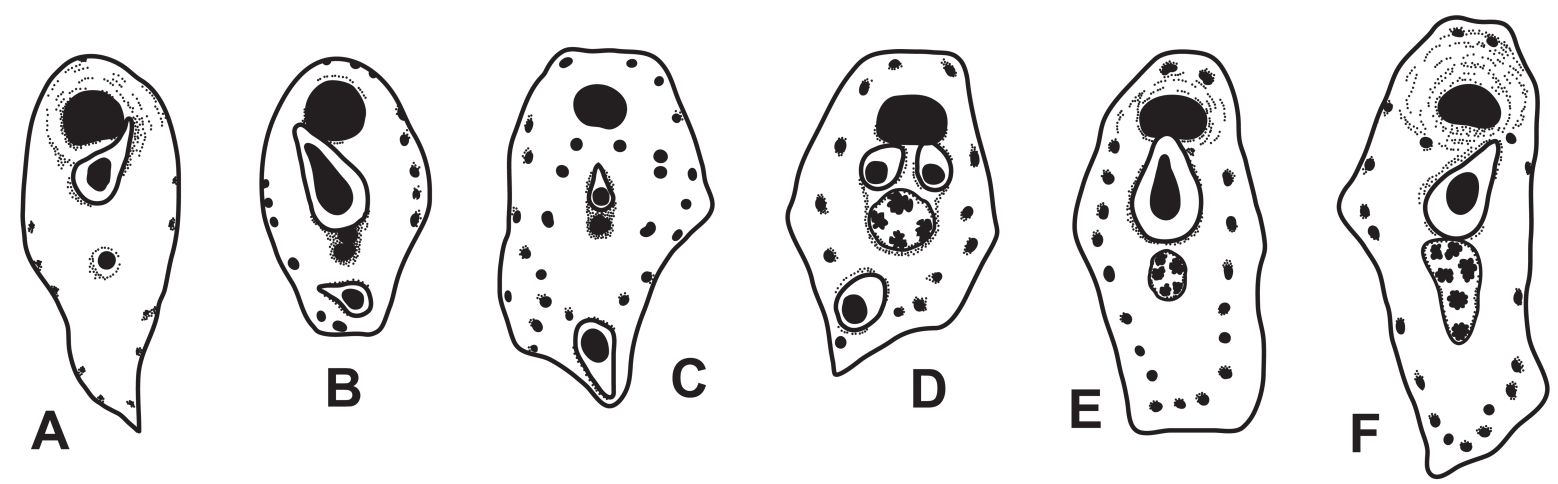

Fig. 17. Schematic drawings of autozooids for the six species of Adeonellopsis MacGillivray, 1886 in Japan. A. A. arculifera (Canu \& Bassler, 1929). B. A. japonica (Ortmann, 1890). C. A. parvirostrum sp. nov. D. A. pentapora Canu \& Bassler, 1929. E. A. sparassis (Ortmann, 1890). F. A. toyoshioae sp. nov. 
Adeonellopsis pentapora is also thought to be widely distributed, occurring in the eastern Pacific from Tasmania to Japan. Mature colonies of A. pentapora are small and often occur as epibionts on substrata such as hydroid stems and gastropod shells inhabited by living hermit crabs. Some hydroids can potentially inhabit soft bottoms, providing substrate for other organisms, and hermit crabs are at least more mobile than sessile bryozoan colonies, which might explain A. pentapora having the broadest distribution in Japan among the adeonids treated in this study (Fig. 18). Adeonellopsis japonica also appears to be widely distributed, occurring along the Pacific coast of Japan and having been reported from Hawaii, more than $6000 \mathrm{~km}$ distant; I did not detect any morphological differences between Japanese and Hawaiian specimens, but genetic studies are needed to clarify whether these populations are cryptic or invasive species.

In Japan, adeonid bryozoans have not been found north of Tsugaru Strait, lying between Hokkaido and Honshu (Fig. 18). This pattern may be correlated with the warm Kuroshio Current and its branches (the Tsushima and Tsugaru Currents), and limited in the north by the cold Oyashio Current (Fig. 1). The lack of records from western Hokkaido despite the extension of the Tsushima current might be due to decreasing effects of the current and colder temperatures, but might also be due to a general lack of collecting in this area, especially in deeper water. Although the Pacific coast of Tohoku (northern Honshu) is influenced by the Oyashio Current, two species (A. japonica and A. pentapora) occur at Otsuchi; this is presumably due to the effects of the Kuroshio and Tsugaru currents, which normally affect nearshore areas more than does the Oyashio Current.
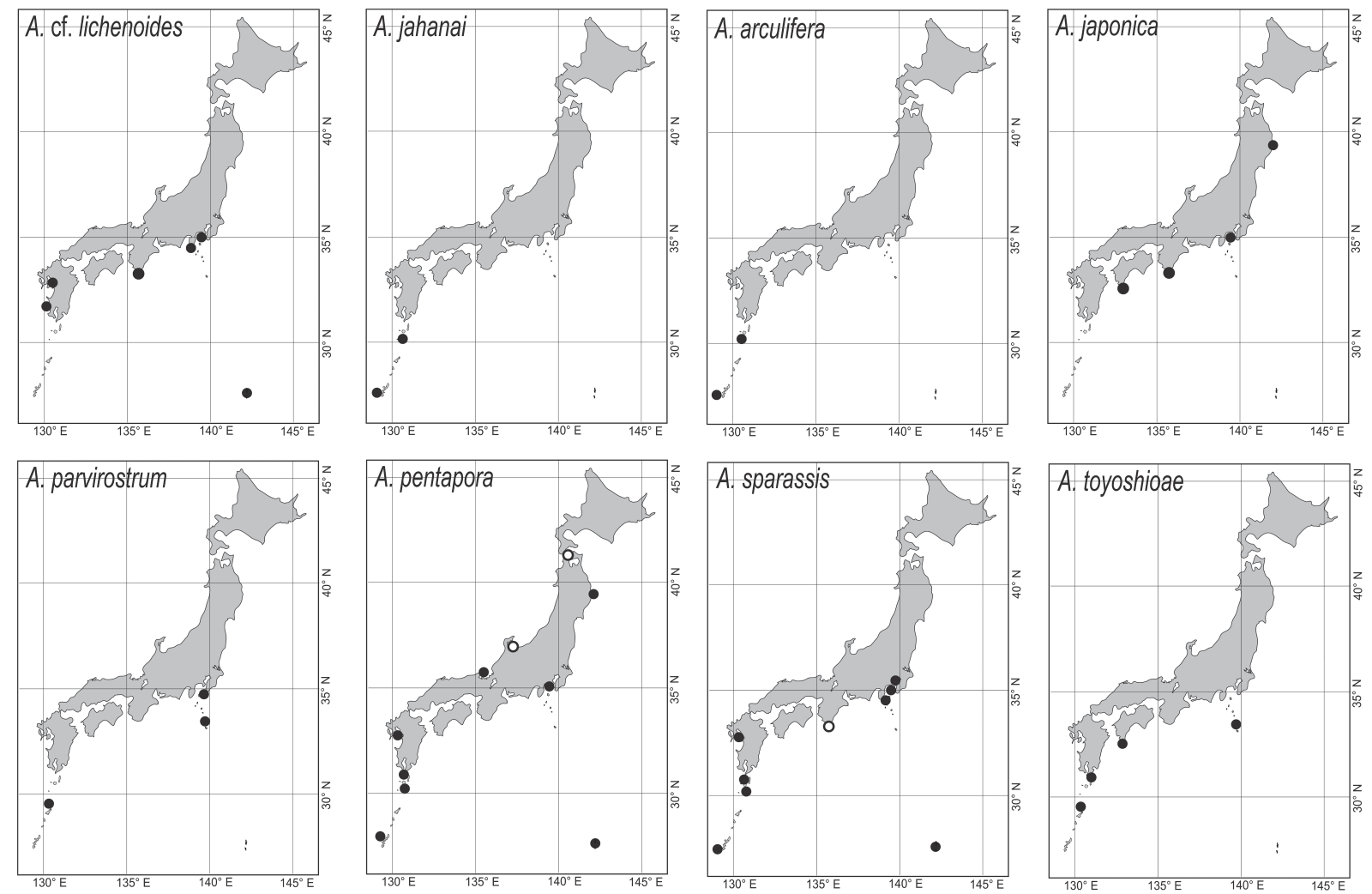

Fig. 18. Maps showing the distribution of the eight adeonid species in Japanese waters. Solid circles indicate sites where a species was detected in this study and unfilled circles indicate records from Canu \& Bassler (1929) and Sakakura (1935) for A. pentapora Canu \& Bassler, 1929, Okada (1920) and Mawatari (1952) for A. sparassis Ortmann, 1890, and Okada \& Mawatari (1935) for A. japonica Ortmann, 1890. 
Adeonellopsis pentapora shows the broadest distribution in Japan, from south of Yakushima to Otsuchi (this study) and Tsugaru Strait (Canu \& Bassler 1929); the paucity of records of A. pentapora from the Sea of Japan is probably due to low sampling effort in this area. Most other adeonid species are distributed in southern Japan, from central Honshu to some point in the Nansei Islands. Adeonella jahanai sp. nov. and Adeonellopsis arculifera, detected only from the Nansei Islands, show the narrowest distributions (Fig. 18).

In the present study, Adeonellopsis toyoshioae sp. nov. was collected from both temperate and subtropical habitats, in areas strongly influenced by the Kuroshio Current. Hayami (1971) described a typically IndoPacific bryozoan fauna from the Miocene to Pliocene Shinzato Tuff in Okinawa, where she reported fossil colonies of $A$. toyoshioae sp. nov., indicating a temperate to subtropical paleoenvironment in this area at the time.

Adeonellopsis japonica is distributed from Kouchi to Otsuchi on the Pacific side of Shikoku and Honshu, but unlike the other species is conspicuously absent from Kyushu and the Nansei Islands (Fig. 18). Although A. japonica has also been reported from Hawaii (Cheetham et al. 1980: USNM 271601, IZ cat 8450; RB 8450), the records there are from deep water (549-605 m). This species thus appears to be distributed in cooler water than the other adeonid species.

\section{Acknowledgments}

I thank Mrs Marie-Dominique Wandhammer and Mrs Marie Meister (Musée Zoologique Strasbourg) for assistance in observations, the loan of the Döderlein Collection, and other help; and Dr Hiroshi Namikawa (Showa Memorial Institute of the National Museum of Nature and Science) for valuable assistance and the loan of the bryozoan collection of Emperor Showa; Dr Joachim Scholz and Mrs Brigitte Lotz (Senckenberg Forsuchung Institute) for assistance during my stay in Germany; Ms. Jo Ann Sanner and Ms. Kathy A. Hollis (Smithsonian Institution, the National Museum of Natural History) for assistance in observation of the USNM bryozoan collection during my stay in Washington; Dr Shigeyuki Yamato (Seto Marine Biological Laboratory, Kyoto University) and Dr Shinta Fujimoto (Kyoto University) for assistance in observing specimens at SMBL studied by Okada and Mawatari; Prof. Susumu Ohtsuka and the crew of T/V Toyoshio-maru (Hiroshima University) for crucial support in field collecting; Dr Asako Matsumoto (Reitaku University) and Mr Masataka Kurosawa, Mr Kouichi Morita, and Mr Masaaki Hirano (International Coastal Research Center, The University of Tokyo) for support in collecting in Otsuchi; Mr Yoshihiko Niiya for collecting and providing bryozoan specimens from Kochi Prefecture; Mr Hisanori Kohtsuka (Misaki Marine Biological Station, The University of Tokyo) for support in collecting in Sagami Bay; Dr Yoshiaki Kai (Maizuru Fisheries Research Station, Kyoto University) for support in collecting in Wakasa Bay; Mr Yoshikazu Jahana for collecting bryozoan specimens around Okinawa; Takuo Higashiji and Hiroko Takaoka (Okinawa Churaumi Aquarium) for providing specimens from Okinawa; Professor Shunsuke Mawatari (Hokkaido University) for much crucial support of this study; Dr Matthew Dick (Hokkaido University) for reviewing and editing drafts of the manuscript; and Dr Björn Berning and an anonymous reviewer for highly constructive comments and suggestions during peer review. This study was supported in part by Grants-in-Aid from the Japan Society for the Promotion of Science (Nos 20-3856 and 23-3410), a Grant-in-Aid from the Kuroshio Biological Research Foundation in 2010, and the research program Tohoku Ecosystem-Associated Marine Science (TEAMS) subsidized by the Ministry of Education, Culture, Sports, Science and Technology (MEXT), Japan. 


\section{References}

Almeida A.C.S., Souza F.B.C., Sanner J. \& Vieira L.M. 2015. Taxonomy of recent Adeonidae (Bryozoa, Cheilostomata) from Brazil, with the description of four new species. Zootaxa 4013 (3): 348-368. http:// dx.doi.org/10.11646/zootaxa.4013.3.2

Amui A.-M. 2005. Adeonellas from the Gulf of Aden including one new species. Zootaxa 1012: 45-52. Arístegui J. 1985. The genus Adeonellopsis MacGillivray (Bryozoa: Cheilostomata) in the Canary Islands: A. distoma (Busk) and A. multiporosa sp. nov. Journal of Natural History 19 (3): 425-430. http://dx.doi.org/10.1080/00222938500770311

Batson P.B. \& Probert P.K. 2000. Bryozoan thickets off Otago Peninsula. New Zealand Fisheries Assessment Report 2000 (46): 1-31.

Berning B., Tilbrook K.J. \& Ostrovsky A.N. 2014. What, if anything, is a lyrula? In: Rosso A., Wyse Jackson P.N. \& Porter J.S. (eds) Bryozoan Studies 2013. Studi Trentini di Scienze Naturali 94: 21-28.

Bock P.E. \& Cook P.L. 2000. Early astogeny of Adeona colonies. In: Herrera Cubilla A. \& Jackson J.B.C. (eds) Proceedings of the 11th International Bryozoology Association Conference: 161-167. Smithsonian Tropical Research Institute, Balboa, Republic of Panama.

Bock P.E. \& Cook P.L. 2004. Dimorphic brooding zooids in the genus Adeona Lamouroux from Australia (Bryozoa: Cheilostomata). Memoirs of Museum Victoria 61 (2): 129-133.

Bock P.E. \& Gordon D.P. 2013. Phylum Bryozoa Ehrenberg, 1831. In: Zhang Z.-Q. (ed.) Animal Biodiversity: An Outline of Higher-level Classification and Survey of Taxonomic Richness (Addenda 2013). Zootaxa 3703: 67-74. http://dx.doi.org/10.11646/zootaxa.3703.1.14

Braga G. 1963. I briozoi del Terziario veneto. I $\mathrm{e}^{\mathrm{e}}$ contributo. Bollettino della Società Paleontologica Italiana 2: 16-55.

Busk G. 1854. Catalogue of Marine Polyzoa in the Collection of the British Museum, II. Cheilostomata (part). Trustees of the British Museum, London. http://dx.doi.org/10.5962/bhl.title.20859

Busk G. 1858. Zoophytology. On some Madeiran Polyzoa. Quarterly Journal of Microscopical Science 6: 124-130. Available from http://www.biodiversitylibrary.org/item/48900\#page/130/mode/1up [accessed 4 May 2016]

Busk G. 1884. Report on the Polyzoa collected by H.M.S. Challenger during the years 1873-76. Part 1. The Cheilostomata. Report on the Scientific Results of the Voyage of H.M.S. 'Challenger', Zoology 10 (30): 1-216. Available from http://www.biodiversitylibrary.org/item/194564\#page/623/mode/1up [accessed 4 May 2016]

Canu F. 1907. Bryozoaires des terrains tertiaires des environs de Paris. Annales de Paléontologie 2: $137-160$.

Canu F. \& Bassler R.S. 1920. North American early Tertiary Bryozoa. United States National Museum Bulletin 106: 1-879. Available from http://www.biodiversitylibrary.org/item/34580\#page/9/mode/1up [accessed 4 May 2016]

Canu F. \& Bassler R.S. 1923. North American later Tertiary and Quaternary Bryozoa. United States National Museum Bulletin 125: 1-302. Available from http://www.biodiversitylibrary.org/ item/33352\#page/7/mode/1up [accessed 4 May 2016]

Canu F. \& Bassler R.S. 1927. Bryozoaires des iles Hawaii. Bulletin de la Société des Sciences de Seineet-Oise 8: 1-67.

Canu F. \& Bassler R.S. 1929. Contributions to the biology of the Philippine Archipelago and adjacent regions. Bryozoa of the Philippine region. United States National Museum Bulletin 100 (9): 1-685. 
Available from http://www.biodiversitylibrary.org/item/32602\#page/5/mode/lup [accessed 4 May 2016]

Carter R.M., Carter L., Williams J.J. \& Landis C.A. 1985. Modern and relict sedimentation on the South Otago Continental Shelf, New Zealand. New Zealand Oceanographic Institute Memoir 93: 1-43.

Cheetham A.H. \& Hayek L.C. 1983. Geometric consequences of branching growth in adeoniform Bryozoa. Paleobiology 9 (3): 240-260

Cheetham A.H., Hayek L.C. \& Thomsen E. 1980. Branching structure in arborescent animals: models of relative growth. Journal of Theoretical Biology 85 (2): 335-369. http://dx.doi.org/10.1016/0022$\underline{5193(80) 90025-9}$

Cook P.L. 1973. Preliminary notes on the ontogeny of the frontal body wall in the Adeonidae and Adeonellidae (Bryozoa, Cheilostomata). Bulletin of the British Museum (Natural History), Zoology 25: 243-263. Available from http://www.biodiversitylibrary.org/item/85287\#page/291/mode/1up [accessed 4 May 2016]

Cook P.L. 1982. Notes on some African Adeonellidae (Bryozoa, Cheilostomata). Journal of Natural History 16 (6): 833-846. http://dx.doi.org/10.1080/00222938200770671

Cuffey R.J. 1974. Delineation of bryozoan roles in reefs from comparison of fossil bioherms and living reefs. Proceedings of the $2^{\text {nd }}$ International Coral Reef Symposium 1: 357-364. The Great Barrier Reef Committee, Brisbane.

Cuffey R.J. 1977. Bryozoan contributions to reefs and bioherms through time. Studies in Geology 4: $181-194$.

David L. \& Pouyet S. 1968. Les Bryozoaires cheilostomes du Chattien de la région de Kassel (Hesse, Allemagne). Geobios 1: 81-102. http://dx.doi.org/10.1016/S0016-6995(68)80003-8

Gregory J.W. 1893. On the British Palaeogene Bryozoa. Transactions of the Zoological Society of London 13: 219-279. Available from http://www.biodiversitylibrary.org/item/97378\#page/305/ mode/1up [accessed 4 May 2016]

Harmer S.F. 1957. The Polyzoa of the Siboga Expedition, Part 4. Cheilostomata Ascophora II. Siboga Expedition Reports 28d: 641-1147.

Hayami T. 1971. Some Neogene Cheilostomata (Bryozoa) from Okinawa-jima. Transactions and Proceedings of the Palaeontological Society of Japan, N.S. 82: 73-92.

Hayward P.J. 1981. The Cheilostomata (Bryozoa) of the deep sea. Galathea Report. Scientific Results of the Danish Deep-Sea Expedition around the world (1950-52) 15: 21-68.

Hayward P.J. 1983. Biogeography of Adeonella (Bryozoa, Cheilostomata): a preliminary account. Bulletin of Marine Science 33: 582-596.

Hayward P.J. 1988. The Recent species of Adeonella (Bryozoa: Cheilostomata) including descriptions of fifteen new species. Zoological Journal of the Linnean Society 94 (2): 111-191. http://dx.doi. org/10.1111/j.1096-3642.1988.tb00105.x

Hayward P.J. \& Cook P.L. 1979. The South African Museum's Meiring Naude Cruises. Part 9, Bryozoa. Annals of the South African Museum 79: 43-130.

Hayward P.J. \& Cook P.L. 1983. The South African Museum's Meiring Naude Cruises. Part 13, Bryozoa II. Annals of the South African Museum 91: 1-161.

Hayward P.J. \& McKinney F.K. 2002. Northern Adriatic Bryozoa from the vicinity of Rovinj, Croatia. Bulletin of the American Museum of Natural History 270: 1-139. 
Hirose M. 2010. Cheilostomatous Bryozoa (Gymnolaemata) from Sagami Bay, with Notes on Bryozoan Diversity and Faunal Changes Over the Past 130 Years. Ph.D. Thesis, Graduate School of Science, Hokkaido University.

Hirose M., Mawatari S.F. \& Scholz J. 2012. Distribution and diversity of erect bryozoans along the Pacific coast of Japan. In: Ernst A., Schäfer P. \& Scholz J. (eds) Bryozoan Studies 2010, Lecture Notes in Earth System Sciences 143: 121-136. http://dx.doi.org/10.1007/978-3-642-16411-8_9

Kataoka J. 1961.Bryozoan fauna from the "Ryukyu Limestone" of Kikai-jima, Kagoshima Prefecture, Japan. The Science Reports of the Tohoku University, Second series, Geology 32 (2): 213-272.

Lamarck J.B.P.A. de M. 1816. Histoire naturelle des Animaux sans Vertèbres ... précédée d'une introduction offrant la détermination des caractéres essentiels de l'animal, sa distinction du végétal et des autres corps naturels, enfin, exposition des principes fondamentaux de la zoologie. Vol. 2. Verdière, Paris. http://dx.doi.org/10.5962/bhl.title.5086

Lidgard S. 1996. Zooidal skeletal morphogenesis of some Australian and New Zealand Adeonellopsis (Cheilostomatida). In: Gordon D.P., Smith A.M. \& Grant-Mackie J.A. (eds) Bryozoans in Space and Time. Proceedings of the 10th International Bryozoology Conference, Victoria University of Wellington, Wellington, New Zealand, 1995: 167-177. NIWA, Wellington.

Lidgard S. \& Buckley G.A. 1994. Toward a morphological species concept in cheilostomates: phenotypic variation in Adeonellopsis yarraensis (Waters). In: Hayward P.J., Ryland J.S. \& Taylor P.D (eds) Biology and Palaeobiology of Bryozoans: 101-105. Olsen \& Olsen, Fredensborg.

Lombardi C., Taylor P.D. \& Cocito, S. 2014. Bryozoan constructions in a changing Mediterranean Sea. In: Goffredo S. \& Dubinsky Z. (eds) The Mediterranean Sea: Its History and Present Challenges: 373-384. Springer, Netherlands. http://dx.doi.org/10.1007/978-94-007-6704-1_21

MacGillivray P.H. 1880. Polyzoa. In: McCoy F. (ed.) Prodromus of the Zoology of Victoria Vol. 1. Decade V: 27-52. Melbourne. Available from http://www.biodiversitylibrary.org/item/27591\#page/341/ mode/1up [accessed 4 May 2016]

MacGillivray P.H. 1886. Descriptions of new, or little-known, Polyzoa, Part 9. Transactions and Proceedings of the Royal Society of Victoria 22: 128-139. Available from http://www.biodiversitylibrary. org/item/105661\#page/392/mode/1up [accessed 4 May 2016]

Mawatari S. 1952. Bryozoa of Kii Peninsula. Publications of the Seto Marine Biological Laboratory 2: 261-288.

McKinney F.K. \& Jackson J.B.C. 1989. Bryozoan Evolution. Unwin Hyman Inc., Boston.

National Science Museum Tokyo. 2007. Fauna Sagamiana. Tokai University Press, Tokyo.

Okada Y. 1918. Taxonomic key and localities of Japanese Cheilostome bryozoans. Doubutsugaku zasshi (Zoological Magazine) 29 (347): 19-20 (277-280). [in Japanese] Available from http://ci.nii.ac.jp/ naid/110003332849 [accessed 26 May 2016]

Okada Y. 1920. Notes on some species of Retepora and Adeonella occurring in Japan, with descriptions of one new variety and five new species. Annotationes Zoologicae Japonenses 9: 613-634. Available from http://www.biodiversitylibrary.org/item/151938\#page/637/mode/1up [accessed 4 May 2016]

Okada Y. 1923. On a collection of Bryozoa from the Straits of Corea. Annotationes Zoologicae Japonenses 10: 215-234.

Okada Y. 1934. Bryozoan Fauna in the Vicinity of the Shimoda Marine Biological Station. Science Reports of the Tokyo Bunrika Daigaku, Section B2, 26: 1-20.

Okada Y. \& Mawatari S. 1935. Bryozoa fauna collected by the 'Misago' during the Zoological Survey around Izu Peninsula (I). Science Reports of the Tokyo Bunrika Daigaku, Section B2, 35: 127-147. 
Okada Y. \& Mawatari S. 1938. On the collection of Bryozoa along the coast of Wakayama-ken, the middle part of Honsyu, Japan. Annotationes Zoologicae Japonenses 17: 445-463.

Ortmann A. 1890. Die japanische Bryozoenfauna. Bericht über die von Herrn Dr. L. Döderlein in Jahre 1880-1881 gemachten Sammlungen. Archiv für Naturgeschäfte 54 (1): 1-74.

Probert P.K. \& Batham E.J. 1979. Epibenthic macrofauna off southeastern New Zealand and mid-shelf bryozoan dominance. New Zealand Journal of Marine and Freshwater Research 13: 379-392.

Rosso A. \& Novosel M. 2010. The genus Adeonella (Bryozoa, Ascophora) in the Mediterranean, with description of two new living species and rediscovery of a fossil one. Journal of Natural History 44: 1697-1727. http://dx.doi.org/10.1080/00222931003760061

Römer F. 1863. Beschreibung der norddeutschen tertiären Polyparien. Palaeontographica Abteilung A Palaeozoologie-Stratigraphie 9: 199-246.

Sakakura K. 1935. Bryozoa from Toyama Bay, Sea of Japan. Annotationes Zoologicae Japonenses 15: 106-118.

Scholz J., Ernst A., Batson P. \& Königshof P. 2005. Bryozoenriffe. Denisia 16: 247-262.

Smith A.M., Stewart B., Key M.M. \& Jamet C.M. 2001. Growth and carbonate production by Adeonellopsis (Bryozoa: Cheilostomata) in Doubtful Sound, New Zealand. Palaeogeography, Palaeoclimatology, Palaeoecology 175: 201-210. http://dx.doi.org/10.1016/S0031-0182(01)00372-8

Spencer-Jones M.E., Scholz J., Grischenko A.V. \& Fujita T. 2011. Japanese Bryozoans from the Meiji Era at the Natural History Museum, London, Part 1: the Mitsukuri and Owston Collections. In: Wyse Jackson P.N. \& Spencer Jones M.E. (eds) Annals of Bryozoology 3: Aspects of the History of Research on Bryozoans: 143-162. International Bryozoology Association, Dublin.

Taylor P.D. \& James N.P. 2013. Secular changes in colony-forms and bryozoan carbonate sediments through geological history. Sedimentology 60 (5): 1184-1121. http://dx.doi.org/10.1111/sed.12032

Thornely L.R. 1905. Report on the Polyzoa collected by Professor Herdman, at Ceylon, in 1902. Report to the Government of Ceylon on the Pearl Oyster Fisheries of the Gulf of Manaar 4: 107-130. Available from http://www.biodiversitylibrary.org/item/18248\#page/157/mode/1up [accessed 4 May 2016]

Wass R.E. 1991. Intracolonial variation in the cheilostome genera Adeona and Adeonellopsis. In: Bigey F.P \& d'Hondt J.-L. (eds) Bryozoaires Actuels et Fossiles: Bryozoa Living and Fossil. Bulletin de la Société Sciences Naturelles de l'Ouest de la France, Mémoire HS 1: 523-529. Société des Sciences Naturelles de l'Ouest de la France, Nantes.

Wood A.C.L. \& Probert P.K. 2013. Bryozoan-dominated benthos of Otago shelf, New Zealand: its associated fauna, environmental setting and anthropogenic threats. Journal of the Royal Society of New Zealand 43 (4): 231-249. http://dx.doi.org/10.1080/03036758.2012.756819

Manuscript received: 2 September 2015

Manuscript accepted: 15 February 2016

Published on: 8 June 2016

Topic editor: Rudy Jocqué

Desk editor: Kristiaan Hoedemakers

Printed versions of all papers are also deposited in the libraries of the institutes that are members of the EJT consortium: Muséum national d'Histoire naturelle, Paris, France; Botanic Garden Meise, Belgium; Royal Museum for Central Africa, Tervuren, Belgium; Natural History Museum, London, United Kingdom; Royal Belgian Institute of Natural Sciences, Brussels, Belgium; Natural History Museum of Denmark, Copenhagen, Denmark. 
Appendix 1. Adeonid specimens in museum collections examined in this study.

The deposit column indicates the museum collection: MZS = Musée Zoologique Strasbourg; NSMT = National Museum of Nature and Science Tokyo; SMBL = Seto Marine Biological Laboratory; USNM = National Museum of Natural History. The Collection Name column lists the names of collections and/or collectors. The 'Note' column indicates the state of specimens and/or additional registration numbers of divided specimens.

\begin{tabular}{|c|c|c|c|c|c|c|c|c|}
\hline Deposit & Collection Name & Number & Date & Locality & Depth & Gear & Vessel & Note \\
\hline MZS & $\begin{array}{l}\text { Doederlelin } \\
\text { (collected by Rolle) }\end{array}$ & $1-1$ & 1891 & Yokohama & - & - & - & NSMT-Te747 (SEM) \\
\hline MZS & Döderlein & $1-2$ & 1882 & Sagami Bay & - & - & - & NSMT-Te745 (SEM) \\
\hline MZS & Döderlein & $1-3$ & 1882 & Sagami Bay & - & - & - & NSMT-Te740 (fragment \& SEM) \\
\hline MZS & Döderlein & $2-1$ & 1882 & Sagami Bay & $185 \mathrm{~m}$ & - & - & - \\
\hline MZS & $\begin{array}{l}\text { Döderlein } \\
\text { (collector unclear) }\end{array}$ & $2-2$ & - & Sagami Bay & $185 \mathrm{~m}$ & - & - & NSMT-Te748 (SEM) \\
\hline MZS & Döderlein & $3-1$ & 1882 & Sagami Bay & - & - & - & - \\
\hline MZS & $\begin{array}{l}\text { Döderlein } \\
\text { (collector unclear) }\end{array}$ & $3-2$ & - & Sagami Bay & - & - & - & NSMT-Te739 (fragment \& SEM) \\
\hline MZS & Döderlein & $3-3$ & 1882 & Sagami Bay & $111-277 \mathrm{~m}$ & - & - & NSMT-Te741 (SEM) \\
\hline MZS & Döderlein & $3-4$ & 1882 & Jogashima, Sagami Bay & $185-370 \mathrm{~m}$ & - & - & NSMT-Te742 (SEM) \\
\hline USNM & Albatross & PAL 271601 & 6 May 1902 & Albatross Station D.3916, of Oahu Island, Hawaii & $549-605 \mathrm{~m}$ & Trawl & Albatross & - \\
\hline USNM & Albatross & PAL 271600.A-D & 7 May 1900 & $\begin{array}{l}\text { Albatross Station D.3704, of Honshu Island, Suruga } \\
\text { Bay, Japan }\end{array}$ & $107-275 \mathrm{~m}$ & Trawl & Albatross & - \\
\hline NSMT & Emperor Showa & BryR 36 & 12 Jun. 1934 & Amadaiba, Sagami Bay & $126 \mathrm{~m}$ & - & - & - \\
\hline NSMT & Emperor Showa & BryR 71 & 4 Sep. 1935 & 4 miles south of Jogashima, Sagami Bay & $150 \mathrm{~m}$ & - & - & with SEM specimen \\
\hline NSMT & Emperor Showa & BryR 193 & 13 Jul. 1963 & $2.5 \mathrm{~km}$ SSW of Jogashima, Sagami Bay & $80-90 \mathrm{~m}$ & - & - & with SEM specimen \\
\hline NSMT & Emperor Showa & BryR 206 & 21 Jul. 1963 & Goronbane, off Kurosaki, Sagami Bay & $110 \mathrm{~m}$ & - & - & with SEM specimen \\
\hline NSMT & Emperor Showa & BryR 225 & 14 Jul. 1964 & Kannonzuka-dashi, Amadaiba, Sagami Bay & $70-85 \mathrm{~m}$ & - & - & - \\
\hline NSMT & Emperor Showa & BryR 254 & 21 Jan. 1967 & 4 km SW of Jogashima, Sagami Bay & $93-97 \mathrm{~m}$ & - & - & with SEM specimen \\
\hline NSMT & Emperor Showa & BryR 255 & 8 Feb. 1967 & $3.5 \mathrm{~km} \mathrm{SW}$ of Jogashima, Sagami Bay & $97 \mathrm{~m}$ & - & - & - \\
\hline NSMT & Emperor Showa & BryR 259 & 12 Dec. 1967 & 3 km WSW of Jogashima, Sagami Bay & $90 \mathrm{~m}$ & - & - & with SEM specimen \\
\hline NSMT & Emperor Showa & BryR 260 & 13 Dec. 1967 & 3 km WSW of Jogashima, Sagami Bay & $85 \mathrm{~m}$ & - & - & with SEM specimen \\
\hline NSMT & Emperor Showa & BryR 261 & 24 Jan. 1968 & $\begin{array}{l}\text { Aoyama-dashi to Kannonzuka-dashi, Amadaiba, } \\
\text { Sagami Bay }\end{array}$ & $85-70 \mathrm{~m}$ & - & - & with SEM specimen \\
\hline NSMT & Emperor Showa & BryR 277 & 12 Mar. 1971 & $2.6 \mathrm{~km} \mathrm{SW}$ of Jogashima, Sagami Bay & $90 \mathrm{~m}$ & - & - & with SEM specimen \\
\hline NSMT & Emperor Showa & BryR 292 & 8 Dec. 1973 & Sakune, north Oyama, Suzaki, Izu & $27 \mathrm{~m}$ & - & - & - \\
\hline NSMT & Emperor Showa & BryR 297 & 10 Dec. 1973 & Sakune, north Oyama, Suzaki, Izu & $23-27 \mathrm{~m}$ & - & - & with SEM specimen \\
\hline
\end{tabular}




\begin{tabular}{|c|c|c|c|c|c|c|c|c|}
\hline Deposit & Collection Name & Number & Date & Locality & Depth & Gear & Vessel & Note \\
\hline NSMT & Emperor Showa & BryR 299 & 12 Dec. 1973 & Ikenodan, Suzaki, Izu & $27-31 \mathrm{~m}$ & - & - & with SEM specimen \\
\hline NSMT & Emperor Showa & BryR 303 & 16 Mar. 1975 & Akasaki, Suzaki, Izu & $20-30 \mathrm{~m}$ & - & - & - \\
\hline NSMT & Emperor Showa & BryR 304 & 16 Mar. 1975 & Akasaki, Suzaki, Izu & $20-30 \mathrm{~m}$ & - & - & - \\
\hline NSMT & Emperor Showa & BryR 315 & 15 Jan. 1976 & $500 \mathrm{~m}$ NE of Sakune, Suzaki, Izu & $36-45 \mathrm{~m}$ & - & - & with SEM specimen \\
\hline NSMT & Emperor Showa & BryR 317 & 8 Feb. 1976 & Ebine, off Shirahama, Izu & $27 \mathrm{~m}$ & - & - & with SEM specimen \\
\hline NSMT & Emperor Showa & BryR 324 & 13 Mar. 1977 & Of Tumekizaki, Suzaki, Izu & $30 \mathrm{~m}$ & - & - & for SEM only \\
\hline NSMT & Emperor Showa & BryR 358 & 17 Mar. 1980 & SE of Tsumekizaki, Suzaki, Izu & $36-45 \mathrm{~m}$ & - & - & - \\
\hline NSMT & Emperor Showa & BryR 359 & 17 Mar. 1980 & SE of Tsumekizaki, Suzaki, Izu & $36-45 \mathrm{~m}$ & - & - & with SEM specimen \\
\hline NSMT & Emperor Showa & BryR 362 & 7 Dec. 1980 & Jogane, Suzaki, Izu & $24 \mathrm{~m}$ & - & - & for SEM only \\
\hline NSMT & Emperor Showa & BryR 365 & 8 Dec. 1980 & Zenijima, Suzaki, Izu & $3-20 \mathrm{~m}$ & - & - & with SEM specimen \\
\hline NSMT & Emperor Showa & BryR 367 & 12 Feb. 1981 & Off Shirahama, Izu & $54 \mathrm{~m}$ & - & - & - \\
\hline NSMT & Emperor Showa & BryR 377 & 14 Mar. 1986 & Ohma, Suzaki, Izu & $20 \mathrm{~m}$ & - & - & with SEM specimen \\
\hline NSMT & Sagami Sea & $\mathrm{TeS} 13$ & 16 Mar. 2001 & $\begin{array}{l}\text { W of Arasaki (near Kamegisho), } 35^{\circ} 11^{\prime} 30.96^{\prime \prime} \mathrm{N}, \\
139^{\circ} 34^{\prime} 31.80^{\prime \prime} \mathrm{E} \text { to } 35^{\circ} 11^{\prime} 32.22^{\prime \prime} \mathrm{N}, 139^{\circ} 34^{\prime} 37.50^{\prime \prime} \mathrm{E} \\
\mathrm{N} \text { of Toshima (SW of Izu-Ōshima), }\end{array}$ & $49.3-48.7 \mathrm{~m}$ & gill-net & Maruse-maru & with SEM specimen \\
\hline NSMT & Sagami Sea & TeS 14 & 27 Nov. 2007 & $\begin{array}{l}34^{\circ} 36^{\prime} 57.00^{\prime \prime} \mathrm{N}, 139^{\circ} 15^{\prime} 48.42^{\prime \prime} \mathrm{E} \text { to } 34^{\circ} 36^{\prime} 42.24^{\prime \prime} \mathrm{N} \\
139^{\circ} 16^{\prime} 22.02^{\prime \prime} \mathrm{E}\end{array}$ & $316-328 \mathrm{~m}$ & CB dredge & Tansei-maru & with SEM specimen \\
\hline NSMT & Sagami Sea & TeS 15 & 21 Feb. 2001 & $\begin{array}{l}\text { WNW of Aburatsubo, } \\
35^{\circ} 10^{\prime} 17.2^{\prime \prime} \mathrm{N}, 139^{\circ} 33^{\prime} 51.7^{\prime \prime} \mathrm{E}\end{array}$ & $106 \mathrm{~m}$ & gill-net & Kiyomatsu-maru & with SEM specimen \\
\hline NSMT & Sagami Sea & TeS 16 & 21 Feb. 2001 & $\begin{array}{l}\text { WNW of Aburatsubo, } \\
35^{\circ} 10^{\prime} 17.2^{\prime \prime} \mathrm{N}, 139^{\circ} 33^{\prime} 51.7^{\prime \prime} \mathrm{E}\end{array}$ & $106 \mathrm{~m}$ & gill-net & Kiyomatsu-maru & with SEM specimen \\
\hline NSMT & Sagami Sea & TeS 17 & 16 Mar. 2001 & $\begin{array}{l}\text { W of Arasaki (near Kamegisho), } 35^{\circ} 11^{\prime} 30.96^{\prime \prime} \mathrm{N}, \\
139^{\circ} 34^{\prime} 31.80^{\prime \prime} \mathrm{E} \text { to } 35^{\circ} 11^{\prime} 32.22^{\prime \prime} \mathrm{N}, 139^{\circ} 34^{\prime} 37.50^{\prime \prime} \mathrm{E}\end{array}$ & $49.3-48.7 \mathrm{~m}$ & gill-net & Maruse-maru & - \\
\hline NSMT & Sagami Sea & TeS 18 & 21 Feb. 2000 & $\begin{array}{l}\text { SW of Hayama (W of Sashima), 35¹3'31.1" N, } \\
139^{\circ} 32^{\prime} 10.1^{\prime \prime} \text { E }\end{array}$ & $200 \mathrm{~m}$ & gill-net & Sankyou-maru & - \\
\hline NSMT & Sagami Sea & TeS 19 & 17 Oct. 2003 & $\begin{array}{l}\text { E of Okinose (Entrance or Tokyo Bay), } 35^{\circ} 0^{\prime} 0.00^{\prime \prime} \mathrm{N} \\
139^{\circ} 40^{\prime} 12.00^{\prime \prime} \mathrm{E} \text { to } 35^{\circ} 0^{\prime} 0.00^{\prime \prime} \mathrm{N}, 139^{\circ} 40^{\prime} 12.00^{\prime \prime} \mathrm{E}\end{array}$ & $97-108 \mathrm{~m}$ & dredge & Shinyo-maru & - \\
\hline NSMT & Sagami Sea & $\mathrm{TeS} 20$ & 17 Oct. 2003 & $\begin{array}{l}\text { E of Okinose (Entrance or Tokyo Bay), } 35^{\circ} 0^{\prime} 0.00^{\prime \prime} \mathrm{N} \\
139^{\circ} 40^{\prime} 12.00^{\prime \prime} \mathrm{E} \text { to } 35^{\circ} 0^{\prime} 0.00^{\prime \prime} \mathrm{N}, 139^{\circ} 40^{\prime} 12.00^{\prime \prime} \mathrm{E}\end{array}$ & $97-108 \mathrm{~m}$ & dredge & Shinyo-maru & - \\
\hline NSMT & Sagami Sea & $\mathrm{TeS} 21$ & 25 Oct. 2002 & SW of Boso Peninsula, $34^{\circ} 51^{\prime} \mathrm{N}, 139^{\circ} 40^{\prime} \mathrm{E}$ & $172-135 \mathrm{~m}$ & dredge & Shinyo-maru & - \\
\hline NSMT & Sagami Sea & $\mathrm{TeS} 22$ & 18 Apr. 2002 & $\begin{array}{l}\text { W of Misaki, } 35^{\circ} 8^{\prime} 21.60^{\prime \prime} \mathrm{N}, 139^{\circ} 35^{\prime} 15.60^{\prime \prime} \text { E to } \\
35^{\circ} 8^{\prime} 27.60^{\prime \prime} \mathrm{N}, 139^{\circ} 35^{\prime} 13.20^{\prime \prime} \mathrm{E}\end{array}$ & $74.1-74.1 \mathrm{~m}$ & dredge & Rinkai-maru & - \\
\hline NSMT & Sagami Sea & $\mathrm{TeS} 23$ & 21 Oct. 2003 & $\begin{array}{l}\mathrm{N} \text { of Hachijo-jima, } 33^{\circ} 26^{\prime} 48.00^{\prime \prime} \mathrm{N}, 139^{\circ} 42^{\prime} 42.00^{\prime \prime} \mathrm{E} \text { to } \\
33^{\circ} 27^{\prime} 0.00^{\prime \prime} \mathrm{N}, 139^{\circ} 42^{\prime} 24.00^{\prime \prime} \mathrm{E}\end{array}$ & $170-176 \mathrm{~m}$ & dredge & Shinyo-maru & - \\
\hline NSMT & Sagami Sea & $\mathrm{TeS} 24$ & 21 Oct. 2003 & $\begin{array}{l}\mathrm{N} \text { of Hachijo-jima, } 33^{\circ} 25^{\prime} 60.00^{\prime \prime} \mathrm{N}, 139^{\circ} 41^{\prime} 54.00^{\prime \prime} \mathrm{E} \text { to } \\
33^{\circ} 26^{\prime} 6.00^{\prime \prime} \mathrm{N}, 139^{\circ} 41^{\prime} 36.00^{\prime \prime} \mathrm{E}\end{array}$ & $160-190 \mathrm{~m}$ & dredge & Shinyo-maru & with SEM specimen \\
\hline NSMT & Sagami Sea & TeS 25 & 26 Nov. 2007 & $\begin{array}{l}\text { NWN of Hachijo-jima, } 33^{\circ} 20^{\prime} 54.48^{\prime \prime} \mathrm{N} \\
139^{\circ} 41^{\prime} 11.16^{\prime \prime} \mathrm{E} \text { to } 33^{\circ} 21^{\prime} 4.32^{\prime \prime} \mathrm{N}, 139^{\circ} 40^{\prime} 30.84^{\prime \prime} \mathrm{E}\end{array}$ & $213-185 \mathrm{~m}$ & CB dredge & Tansei-maru & with SEM specimen \\
\hline
\end{tabular}




\begin{tabular}{|c|c|c|c|c|c|c|c|c|}
\hline Deposit & Collection Name & Number & Date & Locality & Depth & Gear & Vessel & Note \\
\hline NSMT & Sagami Sea & TeS 26 & 23 Oct.2003 & $\begin{array}{l}\text { NE of Hachijo-jima, } 33^{\circ} 34^{\prime} 6.00^{\prime \prime} \mathrm{N}, 140^{\circ} 15^{\prime} 54.00^{\prime \prime} \mathrm{E} \\
\text { to } 33^{\circ} 34^{\prime} 24.00^{\prime \prime} \mathrm{N}, 140^{\circ} 16^{\prime} 0.00^{\prime \prime} \mathrm{E}\end{array}$ & $179-182 \mathrm{~m}$ & dredge & Shinyo-maru & with SEM specimen \\
\hline NSMT & Sagami Sea & TeS 27 & 26 Nov. 2007 & $\begin{array}{l}\text { NWN of Hachijo-jima, } 33^{\circ} 20^{\prime} 54.48^{\prime \prime} \mathrm{N} \\
139^{\circ} 41^{\prime} 11.16^{\prime \prime} \mathrm{E} \text { to } 33^{\circ} 21^{\prime} 4.32^{\prime \prime} \mathrm{N}, 139^{\circ} 40^{\prime} 30.84^{\prime \prime} \mathrm{E}\end{array}$ & $213-185 \mathrm{~m}$ & CB dredge & Tansei-maru & - \\
\hline NSMT & Sagami Sea & $\operatorname{TeS} 28$ & 21 Oct. 2003 & $\begin{array}{l}\mathrm{N} \text { of Hachijo-jima, } 33^{\circ} 26^{\prime} 48.00^{\prime \prime} \mathrm{N}, 139^{\circ} 42^{\prime} 42.00^{\prime \prime} \mathrm{E} \text { to } \\
33^{\circ} 27^{\prime} 0.00^{\prime \prime} \mathrm{N}, 139^{\circ} 42^{\prime} 24.00^{\prime \prime} \mathrm{E}\end{array}$ & $200-211 \mathrm{~m}$ & dredge & Shinyo-maru & with SEM specimen \\
\hline NSMT & Sagami Sea & TeS 29 & 25 Oct. 2002 & SW of Boso Peninsula, $34^{\circ} 51^{\prime} \mathrm{N}, 139^{\circ} 40^{\prime} \mathrm{E}$ & $172-135 \mathrm{~m}$ & dredge & Shinyo-maru & with SEM specimen \\
\hline NSMT & Sagami Sea & $\mathrm{TeS} 30$ & 25 Oct. 2002 & SW of Boso Peninsula, $34^{\circ} 51^{\prime} \mathrm{N}, 139^{\circ} 40^{\prime} \mathrm{E}$ & $172-135 \mathrm{~m}$ & dredge & Shinyo-maru & for SEM only \\
\hline SMBL & $\begin{array}{l}\text { SMBL collection } \\
\text { (collector unclear) }\end{array}$ & Brz 17 & Aug. 1936 & $\begin{array}{l}\text { Seto, Kii Peninsula (probably specimens studied by } \\
\text { Okada \& Mawatari 1938) }\end{array}$ & - & - & - & $\begin{array}{l}\text { NSMT-Te1049, } 1052 \\
\text { (fragments) }\end{array}$ \\
\hline
\end{tabular}


Appendix 2. Localities where specimens were collected during recent surveys (right column $=$ NSMT registration numbers).

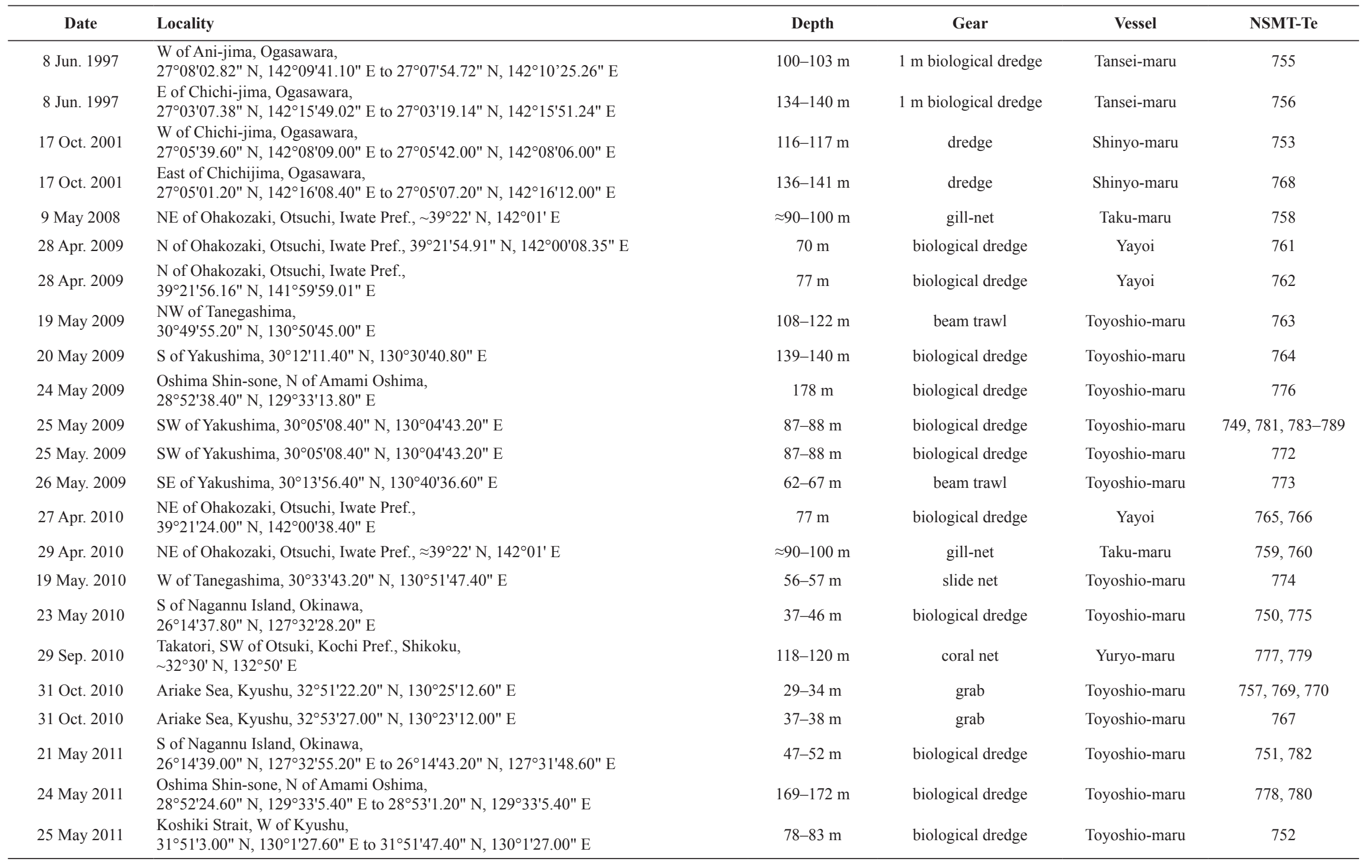




\begin{tabular}{|c|c|c|c|c|c|}
\hline Date & Locality & Depth & Gear & Vessel & NSMT-Te \\
\hline 13 Jan. 2012 & $\begin{array}{l}\text { WSW of Jogashima, Sagami Bay, } \\
35^{\circ} 7^{\prime} 29.04^{\prime \prime} N, 139^{\circ} 33^{\prime} 12.72^{\prime \prime} \text { E to } 35^{\circ} 7^{\prime} 30.24^{\prime \prime} \mathrm{N}, 139^{\circ} 33^{\prime} 37.50^{\prime \prime} \mathrm{E}\end{array}$ & $113-233 \mathrm{~m}$ & biological dredge & Rinkai-maru & 798 \\
\hline 24 Feb. 2012 & $\begin{array}{l}\text { WSW of Jogashima, Sagami Bay, } \\
35^{\circ} 7^{\prime} 18.06^{\prime \prime} \mathrm{N}, 139^{\circ} 33^{\prime} 21.90^{\prime \prime} \mathrm{E} \text { to } 35^{\circ} 7^{\prime} 19.62^{\prime \prime} \mathrm{N}, 139^{\circ} 32^{\prime} 58.68^{\prime \prime} \mathrm{E}\end{array}$ & $300-493 \mathrm{~m}$ & biological dredge & Rinkai-maru & 795 \\
\hline 27 Mar. 2012 & $\begin{array}{l}\mathrm{N} \text { of Kojima Island, Wakasa Bay, } \\
35^{\circ} 43^{\prime} 35.40^{\prime \prime} \mathrm{N}, 135^{\circ} 26^{\prime} 18.60^{\prime \prime} \mathrm{E} \text { to } 35^{\circ} 43^{\prime} 16.80^{\prime \prime} \mathrm{N}, 135^{\circ} 26^{\prime} 14.40^{\prime \prime} \mathrm{E}\end{array}$ & $70.0-85.7 \mathrm{~m}$ & biological dredge & Ryokuyou-maru & 800 \\
\hline 27 May 2012 & $\begin{array}{l}\text { S of Nagannu Island, Okinawa, } \\
26^{\circ} 14^{\prime} 34.68^{\prime \prime} \mathrm{N}, 127^{\circ} 32^{\prime} 1.26^{\prime \prime} \mathrm{E} \text { to } 26^{\circ} 14^{\prime} 36.66^{\prime \prime} \mathrm{N}, 127^{\circ} 31^{\prime} 54.18^{\prime \prime} \mathrm{E}\end{array}$ & $52-54 \mathrm{~m}$ & biological dredge & Toyoshio-maru & $803-804$ \\
\hline 27 May 2012 & $\begin{array}{l}\text { E of Maeshima Island, Okinawa, } \\
26^{\circ} 11^{\prime} 41.40^{\prime \prime} \mathrm{N}, 127^{\circ} 27^{\prime} 20.34^{\prime \prime} \mathrm{E} \text { to } 26^{\circ} 11^{\prime} 39.90^{\prime \prime} \mathrm{N}, 127^{\circ} 27^{\prime} 18.36^{\prime \prime} \mathrm{E}\end{array}$ & $55-57 \mathrm{~m}$ & biological dredge & Toyoshio-maru & 805 \\
\hline 28 May 2012 & $\begin{array}{l}\text { S of Iejima Island, Okinawa, } \\
26^{\circ} 39^{\prime} 14.28^{\prime \prime} \mathrm{N}, 127^{\circ} 41^{\prime} 47.52^{\prime \prime} \text { E to } 26^{\circ} 39^{\prime} 19.38^{\prime \prime} \mathrm{N}, 127^{\circ} 41^{\prime} 52.98^{\prime \prime} \mathrm{E}\end{array}$ & 94-95 m & biological dredge & Toyoshio-maru & 801,806 \\
\hline 29 May 2012 & $\begin{array}{l}\text { Oshima Shin-sone, N of Amami Oshima, } \\
28^{\circ} 52^{\prime} 30.66^{\prime \prime} \mathrm{N}, 129^{\circ} 33^{\prime} 13.98^{\prime \prime} \text { E to } 28^{\circ} 52^{\prime} 37.86^{\prime \prime} \mathrm{N}, 129^{\circ} 33^{\prime} 18.78^{\prime \prime} \mathrm{E}\end{array}$ & $165-200 \mathrm{~m}$ & biological dredge & Toyoshio-maru & $807-808$ \\
\hline 30 May 2012 & $\begin{array}{l}\mathrm{N} \text { of Tanegashima Island, } \\
30^{\circ} 53^{\prime} 19.02^{\prime \prime} \mathrm{N}, 131^{\circ} 2^{\prime} 33.90^{\prime \prime} \text { E to } 30^{\circ} 53^{\prime} 20.16^{\prime \prime} \mathrm{N}, 131^{\circ} 2^{\prime} 44.82^{\prime \prime} \mathrm{E}\end{array}$ & $165-200 \mathrm{~m}$ & biological dredge & Toyoshio-maru & 802 \\
\hline 8 Aug. 2012 & $\begin{array}{l}\text { S of Kanae-zaki, Tosashimizu, Kochi Pref., Shikoku, } \\
\sim 32^{\circ} 33^{\prime} 23^{\prime \prime} \text { N, } 132^{\circ} 47^{\prime} 06^{\prime \prime} \text { E }\end{array}$ & $120 \mathrm{~m}$ & coral net & - & 1051 \\
\hline 3 Oct. 2013 & $\begin{array}{l}\text { off Shimoda, Izu Peninsula, } \\
34^{\circ} 38^{\prime} 56.50^{\prime \prime} \mathrm{N}, 138^{\circ} 57^{\prime} 1.80^{\prime \prime} \text { E to } 34^{\circ} 39^{\prime} 11.83^{\prime \prime} \mathrm{N}, 138^{\circ} 57^{\prime} 8.40^{\prime \prime} \mathrm{E}\end{array}$ & $45-49 \mathrm{~m}$ & dredge & RB Tsukuba & $890-892$ \\
\hline
\end{tabular}

